\title{
Tüketicilerin Mobil Bankacılık Uygulamalarını Kullanma Niyetini Etkileyen Faktörler: Uluslararası Bir Karşılaştırma ${ }^{1}$
}

\begin{abstract}
Cevat Söylemez ${ }^{2}$
Ercan Taşkın ${ }^{3}$

Tüketicilerin Mobil Bankacılık Uygulamalarını Kullanma Niyetini Etkileyen Faktörler: Uluslararası Bir Karşılaştırma

Öz

$\mathrm{Bu}$ çalışmanın amacı, tüketicilerin mobil bankacılık uygulamalarına yönelik tutumları ve sürekli kullanma niyetleri üzerinde etkili olan unsurların ortaya çıkarılmasıdır. Bu kapsamda teknoloji kabul modeli ve planlı davranış teorisinde yer alan değişkenler ele alınmıştır. Ayrıca tutumun tahmin edilmesinde algılanan değer, güven, imaj ve uyumluluk değişkenleride araştırmaya dâhil edilmiştir. Türkiye ve İngiltere'den 466 katılımcı ile ampirik olarak test edilen kavramsal bir model sunulmuştur. Veriler yapısal eşitlik modellemesi ve çoklu grup analizi kullanılarak değerlendirilmiştir. Araştırmadan elde edilen sonuçlar tutum üzerinde algılanan fayda, güven ve uyumluluğun anlamlı etkisi olduğunu ortaya koymaktadır. Mobil bankacılık uygulamalarını sürekli kullanma niyeti üzerinde de subjektif norm, tutum ve algılanan davranışsal kontrolün pozitif yönlü etkisi olduğu bulunmuştur. Türkiye ve İngiltere örneklemi açısından subjektif normun sürekli kullanma niyeti üzerindeki etkisi farklılaşmaktadır.

Determinants of Customer' Intention to Use MBanking Apps: A Cross-Nation Study

Abstract

The purpose of this paper is to investigate the factors affecting on customers' attitude and intention to continually use m-banking application(s). All constructs of the technology acceptance model and theory of planned behaviour are studied. Further, perceived value, trust, image and compatibility are also included to predict attitude. A conceptual model is presented, which is empirically tested with 466 respondents from Turkey and England. The data were analyzed using structural equation modelling (LISREL) and multi-group analysis. The results of the paper show that predictors of attitude, including perceived usefulness, trust and compatibility are significant. The paper found for the positive effect of perceived behavioral control, attitudes and subjective norms towards intention to continually use m-banking apps. Significant differences between sample of Turkey and England were found to affect subjective norms on continuous use intention.
\end{abstract}

Anahtar Kelimeler: Mobil Bankacılık Uygulamaları, Kullanma Niyeti, Teknoloji Kabul Modeli, Çok Gruplu Yol Analizi
Keywords: M-banking apps, Use Intention, The Technology Acceptance Model, Multi-Group Path Analysis

\section{Giriş}

Bilgi ve iletişim teknolojilerinde ortaya çıkan gelişmeler ve yaşanan ilerleme, işletmelerin faaliyetlerini etkileyen önemli pazarlama fırsatlarını da beraberinde getirmektedir. Mobil teknolojilerin kullanımı zamanın çok değerli olduğu 21. yüzyılda, bilgi akışının daha hızlı sağlanmasına yardımcı olurken aynı zamanda etkin bir iletişimin kurulmasında da önemli bir rol oynamaktadır (Barutçu, 2008: 259). Bu hızlı gelişme ve değişim bankaların operasyonlarını

\footnotetext{
${ }^{1}$ Bu çalışma, Kütahya Dumlupınar Üniversitesi Sosyal Bilimler Enstitüsü İşletme Anabilim Dalı Doktora programında, Prof. Dr. Ercan Taşkın danışmanlığında Cevat Söylemez tarafından “Mobil Bankacılık Uygulamalarını Kullanmaya Yönelik Tutumların Teknoloji Kabul ve Planlı Davranış Teorisiyle İncelenmesi" ismiyle tamamlanarak 20.04.2018 tarihinde savunulan doktora tezinden türetilmiştir.

2 Arş. Gör. Dr., Kütahya Dumlupınar Üniversitesi IïBF, Uluslararası Ticaret ve Finans Bölümü. cevatsoylemez@hotmail.com, yazar ORCID bilgisi: https://orcid.org/0000-0002-5373-2913.

${ }^{3}$ Prof. Dr., Kütahya Dumlupınar Üniversitesi IiBF, Uluslararası Ticaret ve Finans Bölümü. ercan.taskin@dpu.edu.tr, yazar ORCID bilgisi: https://orcid.org/0000-0001-8499-1013.
} 
yürütme şeklini ve tüketicilerin bankacılık faaliyetlerini önemli ölçüde etkilemektedir (Yoon and Steege, 2013).

Müşterinin bir mobil cihaz (cep telefonu, tablet, cep bilgisayarı vb.) aracılığıyla bankacılık işlemlerini gerçekleştirmek üzere banka ile iletişim kurduğu bir kanal olarak ifade edilen mobil bankacılık (Barnes ve Corbitt, 2003: 275), mobil telekomünikasyon cihazları yardımıyla bankacılık ve finansal hizmetlerin sağlanmasıdır (Tiwari ve Buse, 2007: 73). Mobil bankacılıkta kullanıcı nerede olursa olsun, istediği her saatte bankacılık işlemlerini hızlı ve güvenli bir şekilde mobil cihazı üzerinden gerçekleştirme olanağına sahiptir (Vurucu ve Arı, 2015: 274). Ayrıca mobil bankacılık, kullanıcılara mobil cihaz aracılığıyla mevcut konumlarından bağımsız olarak hesap durumlarını kontrol etme, para aktarma ve hisse alım-satımı vb. bankayla ilişkili işlemlerinin yapılmasını mümkün hale getirmektedir (Tiwari ve Buse, 2007: 63). Böylece zaman ve mekân sınırı olmadan bankacılık işlemleri 7 gün 24 saat dünyanın her yerinden gerçekleştirilebilmektedir.

Mobil bankacılık, müşterilerle bankalar arasındaki mesafeyi kaldırarak kullanıcılara büyük kolaylıklar sağlamaktadır. Dünyanın birçok yerinde mobil bankacılık, bankacılık altyapısı olmayan ya da az olan özellikle uzak ve kırsal alanlarda yaygın bir şekilde kullanılmaktadır. Bu ülkelerin çoğunda, bankalar ve şubeleri yalnızca büyük şehirlerde ya da belli bölgelerde bulunmaktadır. Bu nedenle, müşterilerde bankaya ulaşmak için yüzlerce kilometre yürümek zorunda kalmaktadır. Örneğin İran, Guatemala ve Meksika gibi ülkelerde müşteriler yerel mobil ağlar üzerinden mobil bankacılığa ulaşabilmektedir (Khraim vd., 2011: 97). Avrupa genelinde akıllı telefon sahiplerinin \%57'si, tablet sahiplerinin \%50'si bu cihazlarla en az 1 kez mobil bankacılığı kullanmıştır (ING Mobil Bankacılık Raporu, 2017). İngiltere'de 2012 yılından 2017 yılına kadar mobil bankacılık uygulamalarını kullananların sayısı \%354 artmış, uygulamalar üzerinden cari hesaplara erişim oranı ise \%21'den \%61'e ulaşmıştır (www.bba.org.uk, 2017). Türkiye'de ise mobil bankacılık hizmetini kullanan bireysel müşteri sayısı 2017 yılı Aralık ayı itibariyle 43 milyon 436 bin'dir. Bu kişiler sisteme kayıt oldukları ilk günden bu yana en az bir kez sisteme giriş işlemi gerçekleştirmiştir (www.tbb.org.tr, 2018). Bu açıdan değerlendirildiğinde kullanıcı sayısının her geçen gün giderek arttığı mobil bankacılık kullanıcı davranışının incelenmesi önemli hale gelmektedir.

Bu kapsamda ele alınan bu çalışmada, araştırmacılar tarafından pazarlama alanında farklı birçok konuda davranışların nasıl şekillendiğini açıklama sürecinde kullanılan ve bir sosyal psikoloji teorisi olan Planlı Davranış Teorisi ile Teknoloji Kabul Modeli birleştirilerek bireylerin mobil bankacılık uygulamalarını kullanma davranışları incelenmiştir. Teknoloji Kabul Modeli ve Planlı Davranış Teorisi çerçevesinde ele alınan değişkenlerle bir model ortaya konulmaya çalışılmış, teorilere eklenen farklı değişkenlerle model genişletilmiştir. Öne sürülen bütünleşik model İngiltere ve Türkiye için karşılaştırmalı olarak test edilmiştir. İngiltere'nin dünyada bankacılığın merkezi olarak değerlendirilmesi; Türkiye'ninde bankacılık sektöründeki son yıllardaki hızı ıelişimi nedeniyle araştırma alanı olarak tercih edilmiştir.

\section{Kavramsal Çerçeve ve Araştırma Hipotezleri}

Çalışmada kullanılacak olan teorik modelin oluşturulmasında Davis'in (1989) geliştirmiş olduğu Teknoloji Kabul Modeli ve Ajzen'in (1991) geliştirmiş olduğu Planlı Davranış Teorisinden yararlanılmıştır. Her iki teorinin temelinde Fishbein ve Ajzen (1975) tarafından ortaya atılan Gerekçeli Eylem Teorisi yer almaktadır. Bu kısımda araştırma kapsamında incelenecek olan değişkenlere yönelik ilişkiler tek tek ele alınarak hipotezler açıklanmaya çalışılmıştır. 


\subsection{Algılanan Fayda ve Algılanan Kullanım Kolaylığı}

Teknoloji kabul modeline göre algılanan fayda bir bireyin sistemin kullanımının benimsenmesini, sisteme karşı tutumunu ve kullanma davranışını etkilemektedir (Davis, 1989; Taylor ve Todd, 1995a; Aboelmaged ve Gebba, 2013). Ayrıca algılanan faydanın tutumla önemli derecede ilişkili olduğu (Hanafizadeh vd., 2014) belirtilirken bu faktörün sadece bilgi sistemleri ve bilgi işlem yeniliklerinin benimsenmesinde değil; mobil ticaret, mobil internet, mobil hizmetler, internet bankacılığı ve mobil bankacılığın benimsenmesinde ve kullanılmasında da önemli olduğu vurgulanmaktadır (Chiu vd., 2005; Wang vd., 2006). Örneğin, Wu vd. (2014), internet bankacılığını kullanma davranışı üzerine yaptıkları çalışmada, internet bankacılığını kullanan bireylerin bunu kullanmaktan kaynaklı bankacılık işlemlerini yerine getirme performanslarını artıracaklarına yönelik algıladıkları faydanın, internet bankacılığını kullanmaya yönelik tutumları üzerinde anlamlı etkisi olduğunu bulmuşlardır. Lai ve Yang (2009), bireysel performans ya da verimliliği artırmada mobil bankacılık gibi e-işletme uygulamalarının yararının farkına varılmasının, bu uygulamalara karşı tutumu olumlu yönde etkileyeceğini belirtmektedir

Teknoloji kabul modeline göre bir bireyin davranışa yönelik tutumunu etkileyen değişkenlerden bir diğeri de algılanan kullanım kolaylığıdır. Davis (1989), algılanan kullanım kolaylığını bireyin belli bir sistemi kullanırken çaba harcamadığına yönelik bireysel algı derecesi olarak belirtmektedir. Çünkü Rogers (1983), belirli bir sistemin karmaşıklığının bir inovasyonunun benimsenmesini ve kullanımını zorlaştıracağını ifade etmektedir. Teknoloji kabul modeline göre algılanan kullanım kolaylığı da algılanan fayda gibi bir bireyin sistemin kullanımına karşı tutumunu etkilemektedir (Aboelmaged ve Gebba, 2013). Ayrıca algılanan fayda ve algılanan kullanım kolaylığının sadece bir teknolojik yeniliğin benimsenmesi için önemli bir faktör olarak düşünülmemelidir. Bu bir teknolojinin uzun dönemli kullanımını da etkileyebilen bu yaklaşım, üzerinde durulan bir konudur (Guriting ve Ndubisi, 2006; Ramayah vd., 2005). Literatürdeki çalışmalarda, internet bankacılığının algılanan kullanım kolaylığının kullanmaya yönelik tutum üzerinde, mobil banka teknolojilerinin algılanan kullanım kolaylığının tutum üzerinde etkisi olduğu elde edilen bulgular arasındadır (Wu vd., 2014; Luarn ve Lin, 2005; Hanafizadeh vd., 2014; Doğan vd., 2015). Diğer taraftan Riquelme ve Rios (2010), mobil bankacılığın benimsenmesi ve kullanılmasına yönelik tutumun algılanan kullanım kolaylığından etkilenmesini bankacılık işlemleri için kullanılan araçların küçük ve karmaşık bir sistem olmasına dayandırmaktadır. Bu nedenle, kullanıcılar bu uygulama ve sürecin karmaşıklığını içeren kullanım için gerekli çabayı göstereceklerdir (Aboelmaged ve Gebba, 2013). Bu nedenle aşağıdaki hipotezler öne sürülmüştür.

$\boldsymbol{H}_{1}$ : Mobil bankacılık uygulamalarını kullanan müşterilerin algıladığı fayda düzeyi, mobil bankacılığa yönelik tutumu etkilemektedir.

$\boldsymbol{H}_{1 a}$ : Türkiye'de mobil bankacılık uygulamalarını kullanan müşterilerin algıladığı fayda düzeyi, mobil bankacılığa yönelik tutumu etkilemektedir.

$\boldsymbol{H}_{1 b}$ : Ingiltere'de mobil bankacılık uygulamalarını kullanan müşterilerin algıladığı fayda düzeyi, mobil bankacılığa yönelik tutumu etkilemektedir.

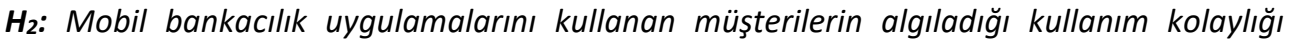
düzeyi, mobil bankacılığa yönelik tutumu etkilemektedir.

$\boldsymbol{H}_{2 a}$ : Türkiye'de mobil bankacılık uygulamalarını kullanan müşterilerin algıladığı kullanım kolaylığı düzeyi, mobil bankacılığa yönelik tutumu etkilemektedir. 
$H_{2 b}$ : Ingiltere'de mobil bankacılık uygulamalarını kullanan müşterilerin algıladığı kullanım kolaylığı düzeyi, mobil bankacılığa yönelik tutumu etkilemektedir.

\subsection{Algılanan Değer}

Değer, ekonomi alanında değişim, fayda ve emek değer teorileriyle birlikte kullanılmasının yanısıra pazarlama, muhasebe, finans, psikoloji ve sosyal psikoloji alanlarında da kullanılmaktadır (Kim vd., 2007). Zeithaml (1988) algılanan değeri, bir tüketicinin ürünün yararı hakkındaki ondan ne aldığı ve ona ne verdiğine ilişkin algılarına dayalı genel değerlendirmesi olarak tanımlamaktadır. Gallarza ve Saura (2006), bir tüketicinin ürün hakkındaki değer algısı analiz edildiğinde yeniden satın alma, ürün seçimi ya da satın alma niyeti gibi tüketici davranışlarının daha iyi anlaşılabileceğini belirtmektedir. Cheng vd. (2006) ele almış oldukları çalışmada, online dağıtım kanalı değerinin kullanıcının maliyet ve verimlilik algısı tarafından belirlendiğini ayrıca düşük maliyet ya da yüksek verimlilik algısının tüketicilerde daha büyük değer algısına yol açtığı ve bunun sonucunda bu kanalı kullanmaya yönelik müşterilerin olumlu tutum sergilediği sonucuna ulaşmışlardır. Wu vd. (2014), müşterilerin algıladığı değerin tutum ve kullanma niyeti üzerindeki etkisini incelemiş ve pozitif yönlü anlamlı etki olduğu sonucuna ulaşmıştır. Bu çalışmada algılanan değer, mobil bankacılığın kullanımından elde edilen fayda ve maliyetin müşteriler tarafından genel bir değerlendirmesi olarak incelenmektedir. Bu kapsamda aşağıdaki hipotez test edilecektir.

$\boldsymbol{H}_{3}:$ Mobil bankacılık uygulamalarını kullanan müşterilerin algıladığı değer düzeyi, mobil bankacılığa yönelik tutumu etkilemektedir.

$H_{3 a}$ : Türkiye'de mobil bankacılık uygulamalarını kullanan müşterilerin algıladığı değer düzeyi, mobil bankacılığa yönelik tutumu etkilemektedir.

$\boldsymbol{H}_{3 b}$ : Ingiltere'de mobil bankacılık uygulamalarını kullanan müşterilerin algıladığı değer düzeyi, mobil bankacılığa yönelik tutumu etkilemektedir.

\subsection{Güven}

Güven, genel olarak bir kişinin herhangi bir güvenlik açığından faydalanmadan, karşı tarafın beklentilerini yerine getirmek için işbirliği içinde hareket edeceğine olan inançtır (Pavlou ve Fygenson, 2006). McKnight vd. (2002), güven - davranış ilişkisinde kişilerin güveni sunanla aralarındaki (kişisel bilgi paylaşımı gibi) belirsizlik ve risk algılamalarının ortadan kaldırılmasına yardımcı olması açısından güvenin önemli olduğunu belirtmektedir. Çeşitli araştırmalarda bilgilere erişim ve finansal transferler gibi bankacılık işlemlerinde (Al Somali vd., 2008; Şıker, 2011; Zandhessami ve Geranmayeh, 2014) ve tüketicilerin internet üzerinden yapılan alışverişe karşı tutumları ve davranışları üzerinde güvenin oldukça önemli bir faktör olduğu belirtilmiştir (Jarvenpaa, 2000; Gefen vd., 2008; Lim vd., 2006). Kim vd. (2009), mobil bankacılık işlemlerinin şube bankacılığına göre daha riskli ve bu tür hizmetlerin kullanılmasında bireyin güven algısının gerekli bir faktör olduğunu ifade etmektedir. Bu araştırma, bireyin bankacılık işlemlerinde mobil bankacılığa yönelik güveni ile mobil bankacılığı kullanmaya yönelik tutumu arasında ilişki bulunduğunu varsaymaktadır. Güven'le ilgili olarak test edilecek olan hipotez aşağıdaki gibidir.

$\boldsymbol{H}_{4}$ : Mobil bankacılık uygulamalarını kullanan müşterilerin algıladığı güven düzeyi, mobil bankacılığa yönelik tutumu etkilemektedir.

$\boldsymbol{H}_{4 a}$ : Türkiye'de mobil bankacılık uygulamalarını kullanan müşterilerin algıladığı güven düzeyi, mobil bankacılığa yönelik tutumu etkilemektedir. 
$H_{4 b:}$ Ingiltere'de mobil bankacılık uygulamalarını kullanan müşterilerin algıladığı güven düzeyi, mobil bankacılığa yönelik tutumu etkilemektedir.

\subsection{Imaj}

Bireyler genellikle bir referans grup içinde olumlu bir görüntü oluşturmak ya da bunu sürdürmek için sosyal normatif etkilere karşı tepki gösterirler (Venkatesh ve Davis, 2000). Olumlu görüntü olarak ifade edilen imaj, kişinin bir yeniliği benimseme/kullanma derecesinin sosyal sistemindeki imajını veya statüsünü artıracağına yönelik algısı olarak ifade edilmektedir (Moore ve Benhasat, 1991; Karahanna vd., 1999).

Mobil bankacılık, bireyler tarafından stratejik avantajlar elde etmek için bir imaj ürünü olarak kullanılabilir (Tiwari vd., 2006). Tiwari vd. (2006), bir imaj ürün olarak mobil bankacılık hizmetlerinin sunulmasının yenilik arayan müşterilerin kazanılmasına yardımcı olabileceğini ve aynı zamanda teknolojik yeniliklere duyarlı müşterilerin bağııı̆ını artırabileceğini belirtmektedir. Puschel vd.'de (2010) ele aldıkları çalışmada, Brezilyalı mobil bankacılık hizmetlerini kullanan ve kullanmayanların imaj algılarının tutum üzerinde etkisi olmadığı bulgusuna ulaşmışlardır. Bu nedenle, müşterilerin mobil bankacılık hizmetlerini kullanmaktan kaynaklı algıladıkları imajın onların mobil bankacılığa yönelik tutumları üzerinde ne yönde etkili olduğunun incelenmesi önemli bir konu haline gelmektedir. Bu amaçla aşağıdaki hipotez test edilecektir.

$H_{5}:$ Mobil bankacılık uygulamalarını kullanan müşterilerin algıladığı kişisel imaj düzeyi, mobil bankacılığa yönelik tutumu etkilemektedir.

$\boldsymbol{H}_{5 a}$ : Türkiye'de mobil bankacılık uygulamalarını kullanan müşterilerin algıladığı kişisel imaj düzeyi, mobil bankacılığa yönelik tutumu etkilemektedir.

$\boldsymbol{H}_{5 b}$ : Ingiltere'de mobil bankacılık uygulamalarını kullanan müşterilerin algıladığı kişisel imaj düzeyi, mobil bankacılığa yönelik tutumu etkilemektedir.

\subsection{Uyumluluk}

Uyumluluk, bir teknolojik yeniliğin var olan sosyo-kültürel değerlerle ve inançlarla, geçmiş deneyimlerle, potansiyel benimseyicilerin/kullanıcıların ihtiyaçlarına bağlı olarak yeniliğin algılanma biçimidir (Rogers, 1983: 223). Yani kullanılan bir teknolojik hizmetin bireyin sahip olduğu değerlerle, deneyimlerle ve intiyaçlarıyla uyumlu olmasıdır. Ilie vd. (2005), bireysel ihtiyaçlar ve teknoloji arasında uyumun fazla olmasının istenen bir durum olduğunu vurgulamaktadır. Vijayasarathy (2004), uyumluluğun online işlemlere karşı tutumun en iyi göstergesi olduğunu belirtirken; Wu ve Wang (2005)'da elektronik bankacılık hizmetleri ve kullanımına karşı tutumun belirlenmesinde uyumluluğun en eski ve en önemli faktörlerden biri olduğunu belirtmektedirler. Ayrıca yüksek uyumluluk, teknolojinin benimsenmesi ve kullanılması şansını artırmaktadır (Wu ve Wang, 2005). Black vd. (2001), internet bankacılığının kabulü üzerine yaptıkları çalışmada müşterilerin geçmiş deneyimlerinin ve değerlerinin kabul üzerinde anlamlı etkisi olduğu sonucuna ulaşmışlardır. Ayrıca Hanafizadeh vd. (2014)'e göre işletme ve kuruluşların kullandıkları iletişim kanalı, müşterilerin yaşam stili veya ihtiyaçlarıyla uyumlu olmadığında sunulan hizmetin başarılı olması zorlaşmakta ve müşteriler bu hizmetten kaçınmaktadırlar. Buna ek olarak müşterilerin değerleri, deneyimleri ve ihtiyaçlarıyla mobil bankacılığın uyumluluğu hakkındaki algılamaları tutumun bir öncüsü olarak görülmektedir. Mobil bankacılığı kullanmaktan hoşnut olan müşterilerin yaşam tarzı ve tercihlerine uygun hizmet sunan uygulamaları aradığı, bunun için müşterileri çekmek ve elde tutmak için mobil bankacılık hizmetlerinin sunulması esnasında bireylerin yaşam tarzı ve tercihleriyle 
uyumluluğun ihmal edilmemesi zorunludur (Lin, 2011). Bu çalışmada, mobil bankacılığın günlük yaşam tarzı ve ihtiyaçları ile uyumlu olduğunu düşünen bireylerin mobil bankacılığın kullanımına karşı olumlu tutum geliştirmeleri beklenmektedir. Bu amaçla aşağıdaki hipotez test edilecektir.

$H_{6}$ : Mobil bankacılık uygulamalarını kullanan müşterilerin algıladığı uyumluluk düzeyi, mobil bankacılığa yönelik tutumu etkilemektedir.

$H_{6 a}$ : Türkiye'de mobil bankacılık uygulamalarını kullanan müşterilerin algıladığı uyumluluk düzeyi, mobil bankacılığa yönelik tutumu etkilemektedir.

$H_{6 b}$ : Ingiltere'de mobil bankacılık uygulamalarını kullanan müşterilerin algıladığı uyumluluk düzeyi, mobil bankacılığa yönelik tutumu etkilemektedir.

\subsection{Tutum, Subjektif Norm ve Algılanan Davranışsal Kontrol}

Niyet, planlı davranış teorisinde niyetin kavramsal olarak birbirinden bağımsız üç tahmincisi olan davranışa yönelik tutum, subjektif normlar ve algılanan davranışsal kontrolle tahmin edilebilmektedir (Ajzen, 1985; 1991). Belirli bir sistemi, uygulamayı ya da yeniliği kullanmaya yönelik olumlu veya olumsuz duygular, sistemi kullanma niyetinin ana belirleyicisi olarak görülmekte ve bunun sonucunda gerçek davranışın elde edilebileceği belirtilmektedir (Ajzen, 1991).

Banka teknolojilerinin benimsenmesi, internet bankacılığının kullanımı davranışı üzerine yapılan çeşitli çalışmalarda, tutum ile benimseme davranışı ve kullanma niyeti arasında ilişkinin olduğu sonucuna ulaşılmış ve niyetin önemli bir açıklayıcısı olarak bireyin davranışa yönelik sahip olduğu tutum bulunmuştur (Puschel vd., 2010; Aboelmaged ve Gebba, 2013; Wu vd., 2014).

Niyetin diğer açıklayıcısı olan subjektif norm, belirli bir davranışı benimseme konusundaki algılanan toplumsal baskıyı belirtmektedir (Ajzen, 1985). Toplumsal baskı, davranışı yerine getirecek olan kişiye aynı sosyal grupta yer alan aile, arkadaş ve çalışma ortamındaki çeşitli gruplar tarafından uygulanabilir. Pedersen (2005), mobil hizmetler bağlamında toplumsal baskının mobil ticareti kullanma niyetinin önemli bir açıklayıcısı olduğu sonucuna ulaşmıştır. Wu vd. (2014), internet bankacılığının benimsenmesine yönelik ele almış oldukları çalışmada, subjektif normun davranışsal niyet üzerinde pozitif yönlü ve anlamlı bir etkisi olduğunu bulmuştur. Ayrıca belirtilen araştırmalara ek olarak subjektif normların internet bankacılığının benimsenmesinin yanısıra e-ödeme ve diğer online işlemlerin benimsenmesini de pozitif yönde etkilediği belirtilmektedir (Gu vd., 2009; Puschel vd., 2010).

Niyetin diğer açıklayıcısı olan algılanan davranışsal kontrol, kişinin davranışını gerçekleştirme yeterliliğini veya yeteneğini algılamasıdır. Kişi yeterli kaynak ve imkana sahip olduğunu düşünürse engelleri düşük algılamakta ve algıladığı davranışsal kontrol düzeyi artmaktadır (Ajzen, 1991). Puschel vd. (2010) ve Wu vd. (2014) tarafından yapılan araştırmalarda davranışsal kontrolün benimseme ve kullanma niyeti üzerinde anlamlı etkisi bulunmuştur.

Taylor ve Todd (1995a), bilgi teknolojilerinin kullanımına yönelik davranışsal niyetleri açıklamak üzere planlı davranış teorisinden yararlanmış; davranışa yönelik tutum, subjektif normlar ve algılanan davranışsal kontrolün niyeti açıklama oranını \%60 olarak bulmuşlardır. Ele almış olduğumuz bu çalışmada da niyet değişkeni, bireylerin mobil bankacılığı kullanmaya yönelik eğilimlerini diğer bir ifadeyle kullanmaları hususundaki olasılığı; tutum değişkeni ise, bireylerin mobil bankacılığı kullanma konusundaki olumlu ya da olumsuz hislerini ifade etmektedir. Ayrıca subjektif norm, mobil bankacılı̆̆ı kullanmak ya da kullanmamaktan kaynaklı 
algılanan sosyal baskıya karşılık gelirken; algılanan davranışsal kontrol ise mobil bankacılığı kullanmanın birey için ne kadar kolay ya da zor olarak algılandığını yani bireyin mobil bankacılığı kullanmasının ne derece kendi kontrolü altında olduğuna ilişkin inancına karşılık gelmektedir. Mobil bankacılığı kullanmaya yönelik tutum ne kadar olumluysa, subjektif normlar ve algılanan davranışsal kontrol ne kadar yüksekse mobil bankacılı̆̆ı kullanma niyeti de o kadar güçlü bir ihtimal olarak değerlendirilebilir. Sonuç olarak, mobil bankacılığı kullanmaya yönelik tutum, subjektif norm ve algılanan davranışsal kontrol ile mobil bankacılığı kullanma niyeti arasındaki ilişki çeşitli açılardan ele alınmaktadır. Bu nedenle aşağıdaki hipotezler test edilecektir.

H7: Mobil bankacılık uygulamalarını kullanan müşterilerin mobil bankacılığa yönelik tutum düzeyi, kullanma niyetini etkilemektedir.

$H_{7 a}$ : Türkiye'de mobil bankacılık uygulamalarını kullanan müşterilerin mobil bankacılığa yönelik tutum düzeyi, kullanma niyetini etkilemektedir.

$H_{7 b}$ : Ingiltere'de mobil bankacılık uygulamalarını kullanan müşterilerin mobil bankacılığa yönelik tutum düzeyi, kullanma niyetini etkilemektedir.

$H_{8}:$ Mobil bankacılık uygulamalarını kullanan müşterilerin sahip olduğu öznel norm düzeyi, kullanma niyetini etkilemektedir.

$H_{8 a}$ : Türkiye'de mobil bankacılık uygulamalarını kullanan müşterilerin sahip olduğu öznel norm düzeyi, kullanma niyetini etkilemektedir.

$H_{8 b}$ : Ingiltere'de mobil bankacılık uygulamalarını kullanan müşterilerin sahip olduğu öznel norm düzeyi, kullanma niyetini etkilemektedir.

Hg: Mobil bankacılık uygulamalarını kullanan müşterilerin algıladığı davranışsal kontrol düzeyi, kullanma niyetini etkilemektedir.

Ha: Türkiye'de mobil bankacılık uygulamalarını kullanan müşterilerin algıladığı davranışsal kontrol düzeyi, kullanma niyetini etkilemektedir.

Hgb: Ingiltere'de mobil bankacılık uygulamalarını kullanan müşterilerin algıladığı davranışsal kontrol düzeyi, kullanma niyetini etkilemektedir. 


\section{Araştırmanın Metodolojisi}

\subsection{Araştırma Modeli}

Çalışmada kullanılacak olan teorik modelin oluşturulmasında Davis'in (1989) geliştirmiş olduğu Teknoloji Kabul Modeli ve Ajzen'in (1991) geliştirmiş olduğu Planlı Davranış Teorisinden yararlanılmıştır. Araştırmada incelenecek olan hipotezler araştırma modelinin yer aldığı Şekil 1 'de gösterilmektedir.

\section{Şekil 1: Araştırma Modeli ve Hipotezler}

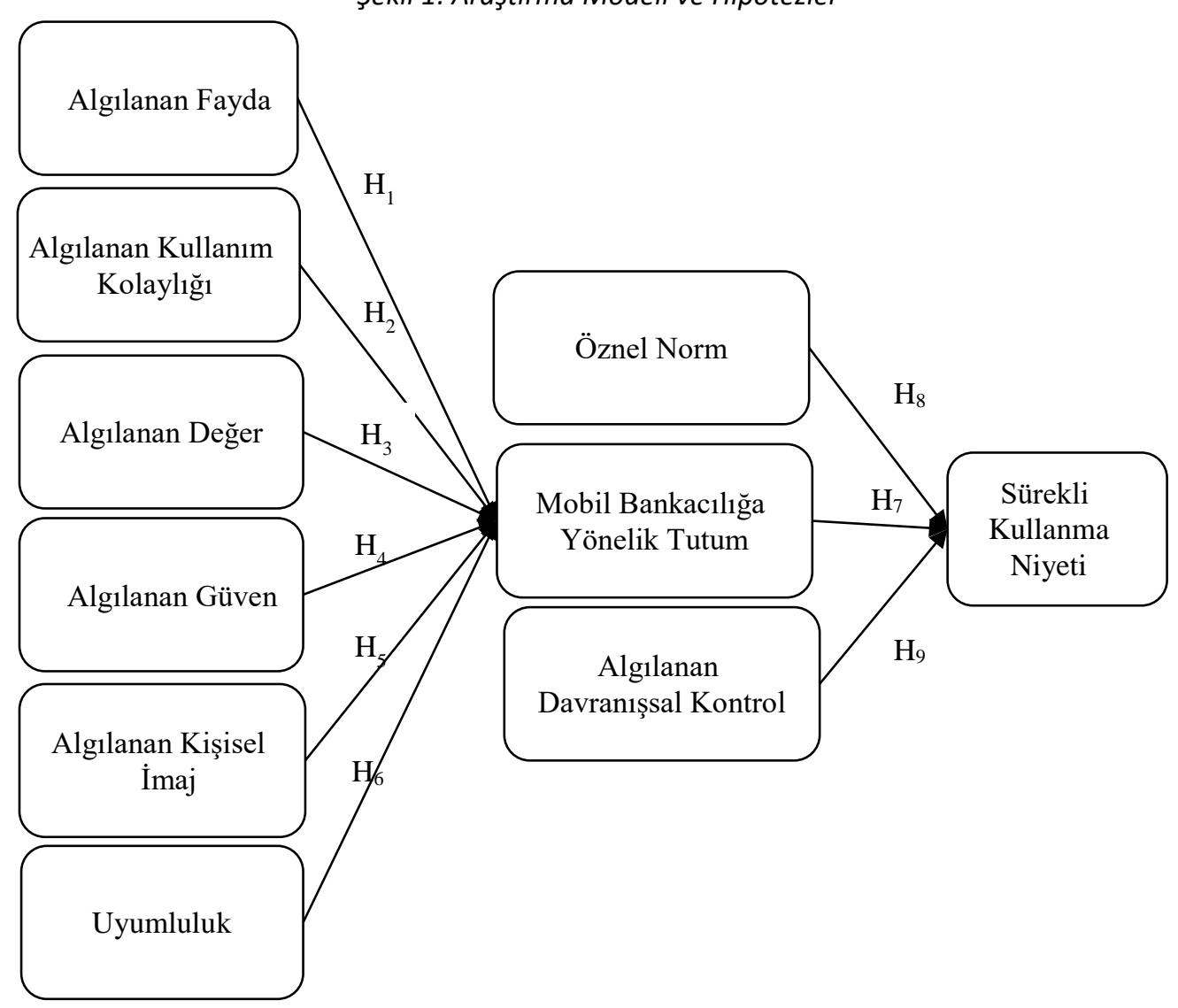

\subsection{Verilerin Toplanması ve Kullanılan Ölçekler}

Verilerin toplanmasında yüz yüze ve online anket yöntemi kullanılmıştır. Araştırmanın amacı doğrultusunda oluşturulan soru formunun ilk kısmında katılımcıların mobil bankacılığa yönelik olarak algıladıkları fayda, algılanan kullanım kolaylığı, algılanan değer, algılanan güven, algılanan kişisel imaj, uyumluluk, öznel norm, mobil bankacılığa yönelik tutum, algılanan davranışsal kontrol ve sürekli kullanma niyeti değişkenlerine ait ifadeler yer almaktadır. İkinci kısımda ise katılımcıların demografik özelliklerini ortaya koyacak sorular, son kısımda da katılımcıların mobil bankacılığı kullanma sıklığı ve gerçekleştirilen işlemlere ilişkin ifadeler yer almaktadır.

Araştırmanın anakütlesini, Türkiye ve İngiltere'de mobil bankacılık uygulamalarını kullanan bireyler oluşturmaktadır. Türkiye Bankalar Birliği'nin verilerine göre Eylül 2017 tarihi itibariyle Türkiye'de mobil bankacılığı kullanan ve son üç ayda 1 kez giriş işlemi yapmış aktif bireysel 
kullanıcı sayısı 26 milyon 536 bin kişidir (www.tbb.org.tr, 2017). İngiliz Bankalar Birliği'nin verilerine göre de 2016 yılı sonu itibariyle İngiltere'de aktif bireysel mobil bankacılık kullanıcı sayısı 19.6 milyon kişidir (www.bba.org.uk, 2017). Bu nedenle araştırma evrenini 46 milyon 136 bin kişi oluşturmaktadır. Bu kapsamda Türkiye'den 256 ve İngiltere'den 208 katılımcı olmak üzere toplam 464 kişiden veri toplanarak araştırmanın örneklem hacmi oluşturulmuştur. Bu ülkelerden veri toplama işleminde kolayda örnekleme yöntemi kullanılmıştır

Anket formunda yer alan ifadelerin değerlendirmesi 5'li Likert (1-Kesinlikle Katılmıyorum, 5Kesinlikle Katılıyorum) şeklinde hazırlanmıştır. Araştırma kapsamında ele alınan algılanan fayda ve algılanan kullanım kolaylığı Davis (1989); algılanan değer Sirdeshmukh vd. (2002) ve Kim vd. (2010); güven Jarvenpaa vd. (2000), Gefen vd. (2003) ve Lim vd. (2006); imaj Moore ve Benbasat (1991) ve Puschel vd. (2010); uyumluluk Moore ve Benbasat (1991), Koenig-Lewis vd. (2010) ve Lin (2011); mobil bankacılı̆̆ı kullanmaya yönelik tutum, öznel norm ve algılanan davranışsal kontrol Taylor ve Todd (1995a), Pedersen (2005) ve Ajzen'in (2005); mobil bankacılığı sürekli kullanmaya yönelik niyete ait ifadeler Li vd. (2006) ve Wu vd. (2014)'nin çalışmalarından uyarlanarak araştırmaya dâhil edilmiştir. Araştırmaya ilişkin ifadeler değerlendirildikten sonra soruların cevaplayıcılar tarafından anlaşılıp anlaşılmadığının ve güvenilirliğinin tespit edilmesi için İngiltere'de 13, Türkiye'de 19 olmak üzere toplam 32 kişiye ön test yapılmıştır.

\section{Verilerin Analizi}

\subsection{Katılımcıların Demografik Özellikleri}

Araştırmaya katılan bireylerin demografik özelliklerine ilişkin bulgular Tablo 1'de detaylı bir şekilde gösterilmektedir. Tablo'ya göre Türkiye'den araştırmaya katılanların \%39,1'inin kadın (101 kişi), \%60,9'unun erkek (157 kişi) ve İngiltere'den katılanların \%70,7'si kadın (147 kişi), \%29,3'ünün erkek (61 kişi) olduğu görülmektedir. Türkiye'den katılanların \%50,0'sinin (129 kişi) 25-34; \%29,1'inin (75 kişi) 35-44 yaş aralığında ve İngiltere'den katılanların \%46,6'sının (97 kişi) 25-34; \%21,2'sinin (44 kişi) 35-44 yaş aralığında olduğu sonucuna ulaşılmıştır. Türkiye örnekleminin \%49,6'sının (128 kişi) üniversite ve İngiltere örnekleminin \%31,3'ünün (65 kişi) üniversite düzeyinde eğitim aldıkları anlaşılmaktadır.

Türkiye örnekleminin \%34,9'unun (90 kişi) haftada birkaç kez; \%35,3'ünün (91 kişi) ayda birkaç kez birkaç mobil bankacılık uygulamalarını kullandı̆̆ı anlaşılmaktadır. İngiltere örnekleminin \%37,5'inin (78 kişi) hergün; \%24,0'ünün (50 kişi) haftada birkaç kez bu uygulamaları kullandığı bulgusu elde edilmiştir. Yine Tablo'ya göre katılımcıların mobil bankacılık uygulamalarını kullanarak en çok faydalandıkları hizmetlerin başında (Türkiye örneklemi için) katılımcıların \%34,9'ı (90 kişi) fatura ödeme; \%23,3'ü (60 kişi) kredi kartı işlemlerinde mobil bankacılık hizmetlerinden faydalandığını belirtmiştir. İngiltere örnekleminin \%26,5'inin (55 kişi) fatura ödeme; \%23,1'inin (48 kişi) mevduat işlemleri için mobil bankacılık uygulamasını kullandığı sonucu elde edilmiştir. 
Eskişehir Osmangazi Üniversitesi ïBF Dergisi

Tablo 1: Katılımcıların Demografik Özellikleri ve Mobil Bankacılı̆̆ı Kullanma Durumu

\begin{tabular}{|c|c|c|c|c|}
\hline & \multicolumn{2}{|c|}{ Türkiye } & \multicolumn{2}{|c|}{ İngiltere } \\
\hline & Frekans & $\%$ & Frekans & $\%$ \\
\hline \multicolumn{5}{|l|}{ Cinsiyet } \\
\hline Kadın & 101 & 39,1 & 147 & 70,7 \\
\hline Erkek & 157 & 60,9 & 61 & 29,3 \\
\hline \multicolumn{5}{|l|}{ Yaş } \\
\hline $16-24$ & 39 & 15,1 & 26 & 12,5 \\
\hline $25-34$ & 129 & 50,0 & 97 & 46,6 \\
\hline $34-44$ & 75 & 29,1 & 44 & 21,2 \\
\hline$>45$ & 15 & 5,8 & 41 & 19,7 \\
\hline \multicolumn{5}{|l|}{ Eğitim } \\
\hline İlköğretim & 16 & 6,2 & 2 & 1,0 \\
\hline Lise & 60 & 23,3 & 15 & 7,2 \\
\hline Önlisans & 29 & 11,2 & 27 & 13,0 \\
\hline Üniversite & 128 & 49,6 & 65 & 31,3 \\
\hline Lisansüstü & 25 & 9,7 & 99 & 47,6 \\
\hline \multicolumn{5}{|c|}{ M-Bankacılık Uygulaması Kullanma } \\
\hline Hergün & 33 & 12,8 & 78 & 37,5 \\
\hline Haftada 1 defa & 20 & 7,8 & 40 & 19,2 \\
\hline Haftada birkaç kez & 90 & 34,9 & 50 & 24,0 \\
\hline Ayda 1 defa & 18 & 7,0 & 18 & 8,7 \\
\hline Ayda birkaç kez & 91 & 35,3 & 14 & 6,7 \\
\hline Yılda 1 defa & 1 & 0,4 & 3 & 1,4 \\
\hline Yılda birkaç kez & 5 & 1,9 & 5 & 2,4 \\
\hline \multicolumn{5}{|c|}{ En Sık Kullanılan Hizmet } \\
\hline EFT/Havale & 69 & 26,8 & 24 & 11,6 \\
\hline Fatura ödeme & 90 & 34,9 & 55 & 26,5 \\
\hline Kredi kartı işlemleri & 60 & 23,3 & 47 & 22,6 \\
\hline Mevduat işlemleri & 22 & 8,5 & 48 & 23,1 \\
\hline Diğer & 17 & 7,5 & 34 & 16,4 \\
\hline Toplam & 258 & 100,0 & 208 & 100,0 \\
\hline
\end{tabular}

\subsection{Güvenirlilik ve Geçerlilik Analizi}

Araştırmada kullanılan ölçeklerin faktör desenlerini ortaya koymak amacıyla faktörleştirme yöntemi olarak temel bileşenler analizi; döndürme yöntemi olarak da dik döndürme yöntemlerinden varimax rotation kullanılmıştır. Açımlayıcı faktör analizine (AFA) ilişkin sonuçlar Tablo 2'de gösterilmektedir. Araştırma kapsamında ele alınan 43 ölçek maddesi için uygulanan açımlayıcı faktör analizinde, faktör yük değerleri için kabul düzeyi 0,50 olarak belirlenmiştir. Algılanan değere ait iki maddenin 0,50 kestirim değerinden küçük faktör yüküne sahip olması, ayrıca kullanma niyetine ait üç maddenin de beklenen yapı altında yer almamasından dolayı analiz dışı bırakılmıştır. Belirlenen on faktörün varyansa yaptıkları toplam katkı ise yaklaşık $\% 82,06$ 'dır. Analiz sonucunda KMO değerinin 0,958 olduğu belirlenmiştir. Bu bulgu doğrultusunda örneklem büyüklüğünün faktör analizi yapmak için mükemmel olduğu sonucuna ulaşılmıştır. Ayrıca Bartlett küresellik testi sonuçları incelendiğinde, elde edilen ki-kare değerinin anlamlı $\left(\chi^{2}(703)=17043,408 ; p<.01\right)$ olduğu görülmektedir. Bu sonuçlar verilerin faktör analizi yapmak çok uygun olduğunu göstermektedir.

Açımlayıcı faktör analizi sonucunda ölçekler Lisrel 8.7 paket programı kullanılarak birinci düzey doğrulayıc faktör analiziyle (DFA) değerlendirilmiştir. Araştırmada değişkenler arasındaki parametrelerin tahmininde En Yüksek Olabilirlik (Maximum Likelihood Estimation) yöntemi kullanılmıştır. DFA analizine ilişkin sonuçlarda Tablo 2'de gösterilmektedir. Ölçme modeline ilişkin olarak elde edilen model uyum iyiliği değerleri $\chi^{2}=1210.40, p<0.01 ; \chi^{2} / d f=1.95$; root mean 
square error of approximation $(\mathrm{RMSEA})=0.045$; comparative fit index $(\mathrm{CFI})=0.99$; normed fit index $(\mathrm{NFI})=0.98$; and non-normed fit index $(\mathrm{NNFI})=0.99$ olarak bulunmuştur. Bu değerler Kline (2011)'na göre iyi uyum değerlerini göstermektedir.

Ölçme modelinin uygunluğu için uyum indeksleri ve faktör yüklerinin dışında güvenirlik ve geçerlilik de değerlendirilmiştir. Hair vd. (2010)'a göre yapısal eşitlik çalışmalarında ölçme modeli için yapı güvenirliği (Composite Reliability) ve ortalama açıklanan varyans (Average Variance Extracted) oranlarının incelenmesi gerekmektedir. Tablo 3'de güvenirlilik ve açıklanan varyans değerlerine yer verilmiştir. Güvenirlilik değerleri (CR) 0,70 değerinin ve açıklanan varyans değerleri (AVE) 0,50'nin üzerindedir. Hair vd.'ne (2010) göre bu göstergeler söz konusu yapıyı temsil etme konusunda yeterlidir.

Tablo 2: Açımlayıcı ve Doğrulayıcı Faktör Analizi Sonuçları

\begin{tabular}{|c|c|c|}
\hline & AFA & DFA \\
\hline \multicolumn{3}{|l|}{ Algılanan Kullanım Kolaylığı } \\
\hline Mobil bankacılığı kullanmayı öğrenmek benim için kolaydır. & 0.720 & 0.83 \\
\hline İstediğim işlemleri yapmak için mobil bankacılığı kullanmak kolay geliyor. & 0.768 & 0.86 \\
\hline Mobil bankacılıkla olan etkileşimim açık ve anlaşıır. & 0.785 & 0.85 \\
\hline Karşılıklı etkileşime geçmek için mobil bankacılığı esnek buluyorum. & 0.722 & 0.74 \\
\hline Mobil bankacılığı kullanmada beceri kazanmak benim için kolaydır. & 0.742 & 0.83 \\
\hline Genel olarak, mobil bankacılığı kullanmanın kolay olduğunu düşünüyorum. & 0.735 & 0.86 \\
\hline \multicolumn{3}{|l|}{ Algılanan Fayda } \\
\hline Mobil bankacılığı kullanmak bankacılık işlemlerimi daha hızlı yapmamı sağlar. & 0.761 & 0.83 \\
\hline Mobil Bankacılığı kullanmak, bankacılık işlemi yapma performansımı artırır. & 0.709 & 0.76 \\
\hline Mobil bankacılığı kullanmak aynı sürede daha fazla bankacılık işlemi yapma imkânı verir. & 0.762 & 0.81 \\
\hline Mobil bankacılığı kullanmak bankacılık işlemlerimi yapma etkinliğimi artırır. & 0.667 & 0.78 \\
\hline Mobil bankacılığı kullanmak bankacılık işlemleri yapmamı kolaylaştırır. & 0.704 & 0.85 \\
\hline Genel olarak, bankacılık işlemlerimi yaparken mobil bankacılığı faydalı buluyorum. & 0.705 & 0.82 \\
\hline \multicolumn{3}{|l|}{ Güven } \\
\hline Mobil bankacılığı kullanmak güvenilirdir. & 0.749 & 0.80 \\
\hline Mobil bankacılığın vaat ve taahhütlerini yerine getirdiğine inanıyorum. & 0.731 & 0.82 \\
\hline Mobil bankacılığın müşterilerin çıkarlarını en iyi şekilde koruyacağına inanıyorum. & 0.801 & 0.87 \\
\hline Genel olarak, Mobil bankacılığa güvenirim. & 0.832 & 0.89 \\
\hline Mobil bankacılık tarafından sağlanan bilgilere güvenirim. & 0.794 & 0.86 \\
\hline \multicolumn{3}{|l|}{ Algılanan Imaj } \\
\hline Mobil bankacılığı kullanmak çevredeki imajımı yükseltir. & 0.751 & 0.73 \\
\hline Çevremde mobil bankacılığı kullanan insanlar kullanmayanlardan daha fazla prestij sahibidir. & 0.888 & 0.88 \\
\hline Çevremde mobil bankacılığı kullananlar seçkin kişilerdir. & 0.883 & 0.90 \\
\hline Çevremde mobil bankacılığı kullanmak bir statü göstergesidir. & 0.888 & 0.89 \\
\hline \multicolumn{3}{|l|}{ Kullanmaya Yönelik Tutum } \\
\hline Mobil bankacılığı kullanmak iyi bir fikirdir. & 0.606 & 0.82 \\
\hline Mobil bankacılığı kullanmak akıllıca bir fikirdir. & 0.710 & 0.88 \\
\hline Mobil bankacılığı kullanma fikrinden hoşlanırım. & 0.712 & 0.89 \\
\hline Mobil bankacılığı kullanmak zevklidir. & 0.657 & 0.82 \\
\hline \multicolumn{3}{|l|}{ Öznel Norm } \\
\hline Davranışımı etkileyen insanlar, mobil bankacılığı kullanmam gerektiğini düşünüyor. & 0.844 & 0.88 \\
\hline Benim için önemli olan insanlar mobil bankacılığı kullanmam gerektiğini düşünüyor. & 0.880 & 0.96 \\
\hline Düşüncelerine değer verdiğim insanlar mobil bankacılığı kullanmam gerektiğini düşüni & 0.852 & 0.91 \\
\hline \multicolumn{3}{|l|}{ Uyumluluk } \\
\hline Mobil bankacılık hayat tarzıma uygundur. & 0.754 & 0.83 \\
\hline Mobil bankacılığı kullanmak tüm bankacılık ve finansal işlemlerimi yönetme şeklime uyg & 0.705 & 0.88 \\
\hline Mobil bankacılığı kullanarak bankacılık işlemlerini gerçekleştirmek çalışma tarzıma uygundur. & 0.629 & 0.90 \\
\hline
\end{tabular}




\begin{tabular}{|c|c|c|}
\hline Mobil bankacılığı kullanabilirim. & 0.562 & 0.89 \\
\hline Mobil bankacılığı kullanabilecek kaynak, bilgi ve beceriye sahibim. & 0.655 & 0.95 \\
\hline Mobil bankacılığı kullanmak tamamen benim kontrolümdedir. & 0.761 & 0.77 \\
\hline \multicolumn{3}{|l|}{ Algılanan Değer } \\
\hline $\begin{array}{l}\text { Ücretleri düşünüldüğünde, kullandığım mobil bankacılık hizmetleri ödediğim paranın karşılığını } \\
\text { veriyor. }\end{array}$ & 0.827 & 0.74 \\
\hline $\begin{array}{l}\text { Tüm parasal ve parasal olmayan maliyetleri düşünüldüğünde, mobil bankacılık hizmetlerini } \\
\text { kullanmak artı değer sağlıyor. }\end{array}$ & 0.672 & 0.91 \\
\hline \multicolumn{3}{|l|}{ Kullanma Niyeti } \\
\hline Mobil bankacılık hizmet sağlayıcım tarafından sağlanan yeni ł & 0.688 & 0.86 \\
\hline Gelecekte mobil bankacılık hizmetlerinden daha fazla yararlanma niyetindeyim. & 0.692 & 0.85 \\
\hline
\end{tabular}

\section{3. Çok Gruplu Doğrulayıcı Faktör Analizi}

Bu aşamada ölçüm modelinin ülke grubu (Türkiye-İngiltere) açısından değişmez olup olmadığı incelenmiştir. Aynı anda farklı grupların karşılaştırılmasına izin veren çok gruplu doğrulayıcı faktör analizi için gerçekleştirilen bu işlem ölçüm değişmezliğidir (Hair vd., 2010: 729). Kline (2011), özellikle sosyal bilimlerde yapılacak grup karşılaştırmalarında ölçmenin en az metrik değişmezlik modeli seviyesinde karşılanması gerektiğini belirtmektedir. Hair vd.'ne (2010) göre, ölçmenin değişmezliği açısından en az metrik değişmezliğin sağlandığı yapılar için çok gruplu yol analizi yapılabilmekte ve nihai yapısal modelin her grup için ayrı ayrı ele alınıp etkileri analiz edilebilmektedir. Araştırma kapsamında bu adımlar kısaca açıklandıktan sonra ülke değişkeni açısından ölçüm değişmezliği analizleri yapılmıştır. Ülke grubu açısından ölçüm değişmezliğine ilişkin sonuçlar Tablo 4'te yer almaktadır. Tablo 4'te yer alan ülke grubuna göre ölçüm değişmezliği sonuçlarına bakıldığında, Türkiye ve Ingiltere için oluşturulan modellerin kabul edilir (Türkiye: $\chi^{2} / d f=1,75 ;$ RMSEA $=0,054 ; C F I=0,98 /$ Ingiltere: $\chi^{2} / d f=1,78 ;$ RMSEA=0,061; $\mathrm{CFI}=0,99)$ uyum iyiliği değerlerine sahip olduğu görülmektedir.

Wu vd. (2007), $\chi^{2}$ farkının örneklem büyüklüğünden etkilenmesinden dolayı çoklu grup karşılaştırmalarında CFI uyum katsayıları arasındaki farkın kullanılması gerektiğini ifade etmektedir. Benzer şekilde, Cheung ve Rensvold (2002)'de ölçme değişmezliği için $\chi^{2}$ farkına güvenilmemesi gerektiğini belirtmektedir. Ölçme değişmezliğinin sağlandığının ifade edilebilmesi için hesaplanan $\Delta$ CFI değerinin 0,01 ile -0,01 değerlerine eşit ya da bu değerler arasında olması istenilen bir durumdur (Kline, 2011). Çoklu grup karşılaştırmaları yapılmadan önce ölçüm değişmezliğinin sağlanması gerekmektedir (Cheung ve Rensvold, 2002). Bu kapsamda incelenen bu araştırmada belirlenen temel model çerçevesinde ölçüm değişmezliği (çok gruplu doğrulayıcı faktör analizi) testi için elde edilen doğrulayıcı uyum katsayıları (CFI) arasındaki farklar incelenmiştir.

\subsubsection{Yapısal Değişmezlik}

Bu test her iki gruba ait faktör yapısının farklılık gösterip göstermediğini analiz etmek için kullanılır. Eğer yapısal değişmezlik sonucunda model veriyle uyum sağlamazsa (model indeksleri anlamsız çıkarsa), ölçüm değişmezliğinin diğer aşamalarına geçilemez (Kline, 2011: 252). Tablo 4'e göre, yapısal değişmezlik (Model 1) sonuçlarının gruplar açısından aynı faktör yapısına sahip olduğu anlaşılmaktadır. Model 1 'e ait sonuçlar $\left(\chi^{2} / d f=2,17 ; \quad C F I=0,97 ; \quad N N F I=0,97 ;\right.$ RMSEA=0,071) kabul edilebilir değerlere sahiptir. Diğer bir ifadeyle yapısal değişmezliğin sağlandığı yani faktör yapılarının aynı olduğu (farklılaşmadığı) ifade edilebilir. Yapısal eşdeğerliliğin test edilmesi için kullanılan on gizil değişkenden oluşan bu ölçüm modeli için elde edilen test istatistiği sonucu; bu on gizil değişkenli yapının iki grup için aynı olduğu sonucunu göstermektedir. 


\subsubsection{Metrik Değişmezlik}

Metrik değişmezlik, gruplara ilişkin faktör yüklerinin özdeş olması durumudur. Bu aşamada $\chi^{2}, d f$ ve CFI değerleri hesaplanır. Sonrasında yapısal değişmezlikten faydalanılarak $\Delta \chi^{2}, \Delta d f$ ve $\Delta C F I$ değerlerine bakılır. Elde edilen $\Delta \chi^{2}$ değerine ilişkin $\mathrm{p}$ değeri $\chi^{2}$ tablosuna bakılarak hesaplanır ve bu değerin metrik değişmezlik için hesaplanan $p>0,05$ değerinden büyük olması ölçümler arasında fark olmadığını ve ölçmenin değişmezliğinin sağlandığını gösterir (Kline, 2011: 254-255). Tablo 4'de yer alan metrik değişmezlik (Model 2) sonuçlarına baktığımızda ise, faktör yüklerinin eşit ve değişmez olduğu görülmektedir. Model 2'ye ait uyum indeksleri sonuçları $\left(\chi^{2} / d f=2,15 ; \mathrm{CFI}=0,97 ; \mathrm{NNFI}=0,97 ; \mathrm{RMSEA}=0,070\right)$ kabul edilebilir değerlerdir. Metrik değişmezlik için Model 2'nin Model 1 ile karşılaştırılması yapılmış ve karşılaştırmada $\triangle C F I$ değerlerine bakılmıştır. Elde edilen $\Delta \mathrm{CFI}=0,00$ değeri; 0,01 değerinden daha düşüktür. $\mathrm{Bu}$ nedenle metrik değişmezlik sağlanmıştır.

Tablo 3: Yapı Geçerliliği, Güvenirlilik ve Ölçüm Modeline Illişkin Korelasyon Matrisi

\begin{tabular}{|c|c|c|c|c|c|c|c|c|c|c|c|c|c|c|}
\hline Değişken & AVE & $\begin{array}{l}\text { AVE'nin } \\
\text { karekökü }\end{array}$ & CR & $\alpha$ & 1 & 2 & 3 & 4 & 5 & 6 & 7 & 8 & 9 & 10 \\
\hline 1 Algılanan Fayda & 0.65 & 0.81 & 0.92 & 0.940 & 1 & & & & & & & & & \\
\hline 2 Al. Kul. Kolaylığı & 0.69 & 0.83 & 0.93 & 0.942 & 0,75 & 1 & & & & & & & & \\
\hline 3 Algılanan Değer & 0.69 & 0.83 & 0.81 & 0.813 & 0,67 & 0,58 & 1 & & & & & & & \\
\hline 4 Algılanan Güven & 0.72 & 0.85 & 0.93 & 0.931 & 0,54 & 0,57 & 0,60 & 1 & & & & & & \\
\hline 5 Al. Kişisel İmaj & 0.73 & 0.85 & 0.91 & 0.913 & 0,02 & 0,06 & 0,09 & 0,24 & 1 & & & & & \\
\hline 6 Uyumluluk & 0.76 & 0.87 & 0.90 & 0.906 & 0,66 & 0,60 & 0,61 & 0,56 & 0,25 & 1 & & & & \\
\hline 7 Öznel Norm & 0.84 & 0.92 & 0.94 & 0.932 & 0,11 & 0,04 & 0,17 & 0,21 & 0,60 & 0,36 & 1 & & & \\
\hline 8 Tutum & 0.73 & 0.85 & 0.91 & 0.922 & 0,69 & 0,59 & 0,59 & 0,60 & 0,19 & 0,73 & 0,31 & 1 & & \\
\hline 9 Al. Dav. Kontrol & 0.76 & 0.87 & 0.91 & 0.907 & 0,68 & 0,66 & 0,53 & 0,50 & 0,02 & 0,62 & 0,09 & 0,68 & 1 & \\
\hline 10 Kullanma Niyeti & 0.73 & 0.85 & 0.84 & 0.856 & 0,64 & 0,53 & 0,58 & 0,54 & 0,21 & 0,66 & 0,32 & 0,77 & 0,67 & 1 \\
\hline
\end{tabular}

Tablo 4: Çok Gruplu DFA Model Uyum Değerleri

\begin{tabular}{|c|c|c|c|c|c|c|c|c|c|}
\hline Model & $x^{2}$ & $d f$ & $\chi^{2} / d f$ & RMSEA & NNFI & CFI & $\Delta \chi^{2}$ & $\Delta d f$ & $\Delta \mathrm{CFI}$ \\
\hline Türkiye (n=258) & 1083,09 & 620 & 1,75 & 0,054 & 0,97 & 0,98 & - & - & - \\
\hline İngiltere ( $n=208)$ & 1101,65 & 620 & 1,78 & 0,061 & 0,98 & 0,99 & - & - & - \\
\hline Model 1 (Yapısal Değişmezlik) & 2962,08 & 1361 & 2,17 & 0,071 & 0,97 & 0,97 & - & - & - \\
\hline Model 2 (Metrik Değişmezlik) & 2846,25 & 1323 & 2,15 & 0,070 & 0,97 & 0,97 & 115,83 & 38 & 0,00 \\
\hline
\end{tabular}

\section{Yol Analizi ve Hipotezlerin Test Edilmesi}

Araştırmaya ilişkin ölçme modeli doğrulandıktan ve ülke grubuna ilişkin ölçüm değişmezliği sağlandıktan sonra kuramsal olarak öne sürülen araştırma modelinin analizi ve hipotezlerin test edilmesi sürecine geçilmiştir. Yapısal modelin testinde de Lisrel 8.7 paket programı kullanılmıştır.

\subsection{Yapısal Modelin (Genel) Test Edilmesi}

Yapısal modelin test edilmesinde öncelikle parametre değerlerinde anormallik olup olmadığı kontrol edilmiştir. Gerçekleştirilen analiz sonucunda gizil değişkenlerin gözlenen 
değişkenleri açıklama durumlarına ilişkin t değerlerinin manidar olduğu anlaşılmıştır. Şekil 2' de araştırmanın yapısal modeline ilişkin diagram gösterilmektedir. Yapısal modele ilişkin $\chi^{2}$ değerinin $\left(\chi^{2}=1247,67 ; d f=628 ; p=0,00\right)$ anlamlı olduğu görülmektedir. Ayrıca $\chi^{2} / d f=1,99$ olması mükemmel uyuma sahip bir modelin temsil edildiğini göstermektedir. Elde edilen RMSEA değeri $(0,046), \operatorname{CFI}(0,99), \operatorname{NFI}(0,98)$ ve NNFI $(0,99)$ mükemmel uyumu göstermektedir.

\section{Şekil 2: Yapısal Yol Analizi (Genel Model)}

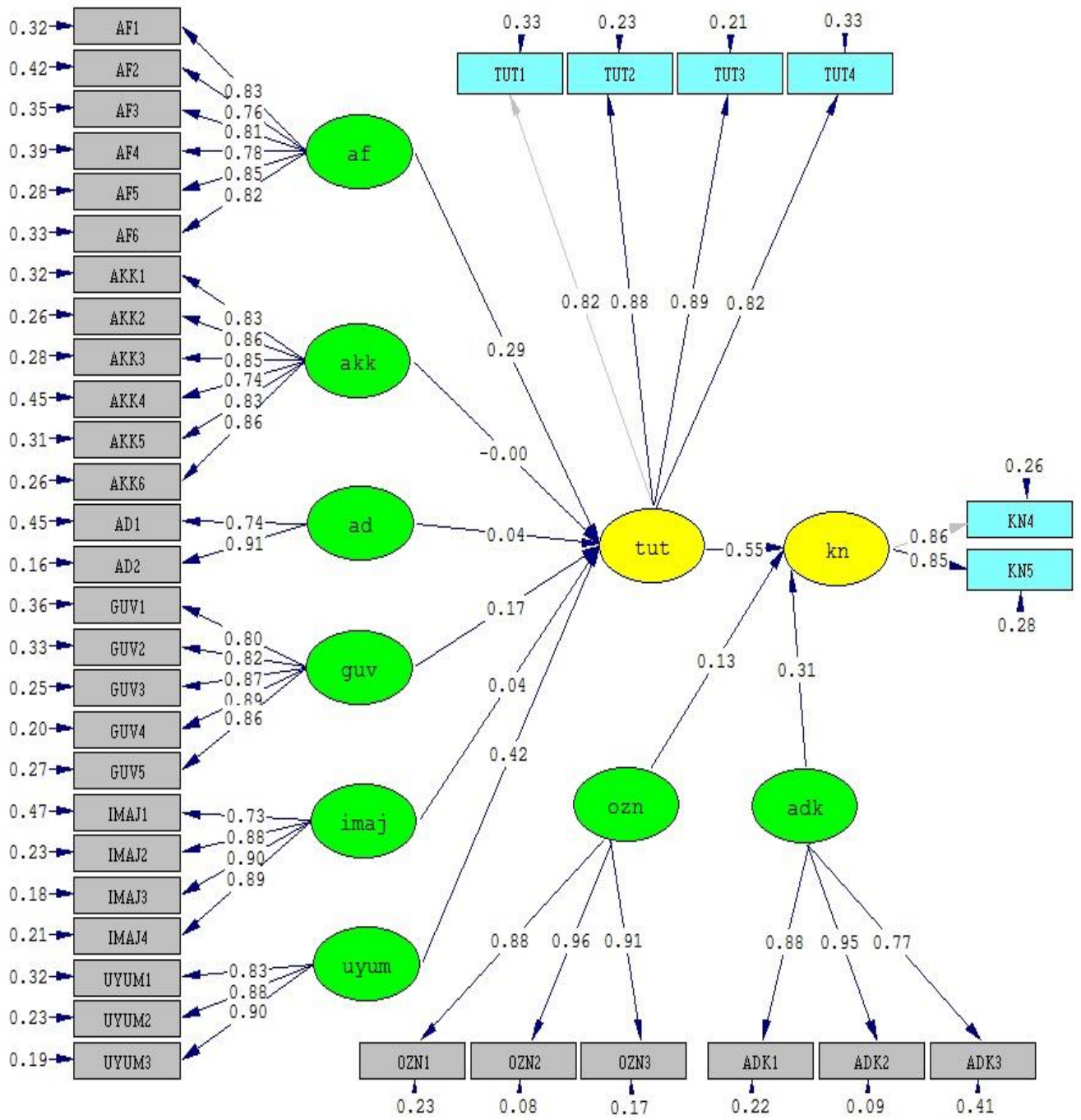

Chi-Square $=1247.67, \mathrm{df}=628, \mathrm{P}-\mathrm{value}=0.00000, \mathrm{RMSEA}=0.046$

Tablo 5'te araştırma modelinde öngörülen ilişkilere ait standardize edilmiş yol katsayıları ve $t$ değerleri yer almaktadır. Sonuçlara göre $t$ değeri 1,96 ve 2,56 arasında olan ilişki $p<0,05$ düzeyinde anlamlı; $t$ değeri 2,56'nın üzerinde olan ilişki $p<0,01$ düzeyinde anlamlı bulunmuştur. Tabloda yer alan $\mathrm{t}$ değerleri incelendiğinde, teorik modelde öngörülenin aksine algılanan 
kullanım kolaylığı ve tutum; algılanan değer ve tutum; algılanan kişisel imaj ve tutum ilişkisinin 0,05 düzeyinde anlamsız çıktığı (t değerleri < 1,96) görülmüştür. Bu nedenle $\mathrm{H}_{2}, \mathrm{H}_{3}$ ve $\mathrm{H}_{5}$ hipotezleri reddedilmiştir. Bu ilişkilerin dışındaki diğer ilişkiler 0,01 düzeyinde anlamlıdır (t değerleri > 2,56). Tabloda yer alan bilgiler doğrultusunda $\mathrm{H}_{1}, \mathrm{H}_{4}, \mathrm{H}_{6}, \mathrm{H}_{7}, \mathrm{H}_{8}$ ve $\mathrm{H}_{9}$ hipotezleri de kabul edilmiştir. Yine tabloya göre; algılanan fayda, algılanan kullanım kolaylığı, algılanan değer, algılanan güven, algılanan kişisel imaj ve uyumluluk mobil bankacılığı kullanmaya yönelik tutumun \%65'ini $\left(R^{2}\right)$ açıklamaktadır. Öznel norm, algılanan davranışsal kontrol ve tutum da mobil bankacılık kullanma niyetinin $\% 65^{\prime}$ ini $\left(R^{2}\right)$ açıklamaktadır.

Tablo 5: Yol Analizi Sonuçları (Genel Model) ve Hipotezler

\begin{tabular}{|c|c|c|c|c|}
\hline $\begin{array}{l}\text { Hipotezler ve } \\
\text { Yapısal ilişki }\end{array}$ & $\begin{array}{l}\text { Standardize Edilmiş } \\
\text { Yol Katsayısı ( } \beta \text { ) }\end{array}$ & t-değeri & $\mathbf{R}^{2}$ & Hipotez Sonucu \\
\hline $\mathrm{H}_{1}:$ af $\rightarrow$ tut & 0,29 & 4,43 & \multirow{6}{*}{0,65} & Kabul \\
\hline $\mathbf{H}_{2}:$ akk $\rightarrow$ tut & 0,00 & 0,05 & & Red \\
\hline $\mathbf{H}_{3}:$ ad $\rightarrow$ tut & 0,04 & 0,70 & & Red \\
\hline $\mathrm{H}_{4}$ : guv $\rightarrow$ tut & 0,17 & 3,44 & & Kabul \\
\hline $\mathbf{H}_{5}:$ imaj $\rightarrow$ tut & 0,04 & 1,08 & & Red \\
\hline $\mathrm{H}_{6}:$ uyum $\rightarrow$ tut & 0,42 & 7,50 & & Kabul \\
\hline $\mathrm{H}_{7}$ : tut $\rightarrow \mathrm{kn}$ & 0,55 & 10,45 & \multirow{3}{*}{0,65} & Kabul \\
\hline $\mathrm{H}_{8}: \mathrm{ozn} \rightarrow \mathrm{kn}$ & 0,13 & 3,58 & & Kabul \\
\hline $\mathrm{H}_{9}: \mathrm{adk} \rightarrow \mathrm{kn}$ & 0,31 & 6,56 & & Kabul \\
\hline
\end{tabular}

\section{2. Çok Gruplu Yol Analizi Sonuçları}

Bu araştırma kapsamında farklı örneklem gruplarının olması nedeniyle bir önceki bölümde oluşturulan yapısal modelin ve modelde yer alan yapısal eşitliklerin örneklem grubu açısından farklılık gösterebileceği değerlendirilmiştir. Bu kapsamda farklılıkların değerlendirilmesi için çok-gruplu yapısal eşitlik modellemesi kullanılmıştır. Kline (2011) ve Hair vd. (2010), grup karşılaştırma modellerinde belirli kriterlerin sağlanması gerektiğini ifade etmektedir. Bunun için en önemli kriter ölçüm değişmezliğinin sağlanması koşuludur. Ölçüm değişmezliği ile yapısal modelde kullanılan ölçüm modelinin her grup açısından değişmezliği ve aynı şekilde kullanılabileceğini ifade etmektedir. Araştırmaya ilişkin ölçüm değişmezliği için değişmezlik testleri daha önce yapılmıştı ve araştırma verilerinin ölçüm değişmezliğini sağladığı sonucuna ulaşılmıştı.

Yapısal çoklu grup karşılaştırmalarında öncelikle gruplar arasında öne sürülen model açısından bir farklılık olup olmadığı tespit edildikten sonra grupların ayrı ayrı model açısından farklılıkların belirlenmesi tavsiye edilmektedir (Şimşek, 2007: 163-165). Bu kapsamda araştırma modelinin Türkiye ve İngiltere grupları açısından farklılaşıp farklılaşmadığına bakılmıştır ve elde edilen uyum iyiliği değerleri $\left(\chi^{2}=2875.32 ; d f=1320 ; \chi^{2} / d f=2,18 ; \operatorname{RMSEA}=0.071 ; \mathrm{CFI}=0.97\right.$; $\mathrm{NFI}=0.95 ; \mathrm{NNFI}=0.97$ ) gruplar arasında yapısal anlamda fark olduğunu göstermektedir. $\mathrm{Bu}$ nedenle $\mathbf{H}_{\mathrm{A}}$ hipotezi (araştırma modeli ülke grubuna göre farklılaşmaktadır) desteklenmiştir. Bundan sonraki aşamada ise gruplarda nasıl farklılıklar olduğunu görebilmek için her grupta ayrı ayrı yapısal analiz yapılmıştır. 
Türkiye örneklemi için gerçekleştirilen analiz sonucuna ait yapısal modelin grafiksel gösterimi Şekil 3'te gösterilmektedir. Yapısal modele ilişkin $\chi^{2}$ değerinin $\left(\chi^{2}=1112,86 ; d f=628\right.$; $p=0,00$ ) anlamlı olduğu görülmektedir. Ayrıca $\chi^{2} / d f=1,77$ olması mükemmel uyuma sahip bir modelin temsil edildiğini göstermektedir. RMSEA değeri $(0,055)$ 'de kabul edilebilir iyi uyumu temsil etmektedir. Türkiye örneklemine ait yapısal modele ilişkin $\operatorname{CFI}(0,98), \operatorname{NFI}(0,94)$ ve NNFI $(0,97)$ değerleri de modelin mükemmel uyuma sahip olduğu sonucunu ortaya koymuştur.

Şekil 3: Türkiye Örneklemine Iliş̧kin Yol Diagramı

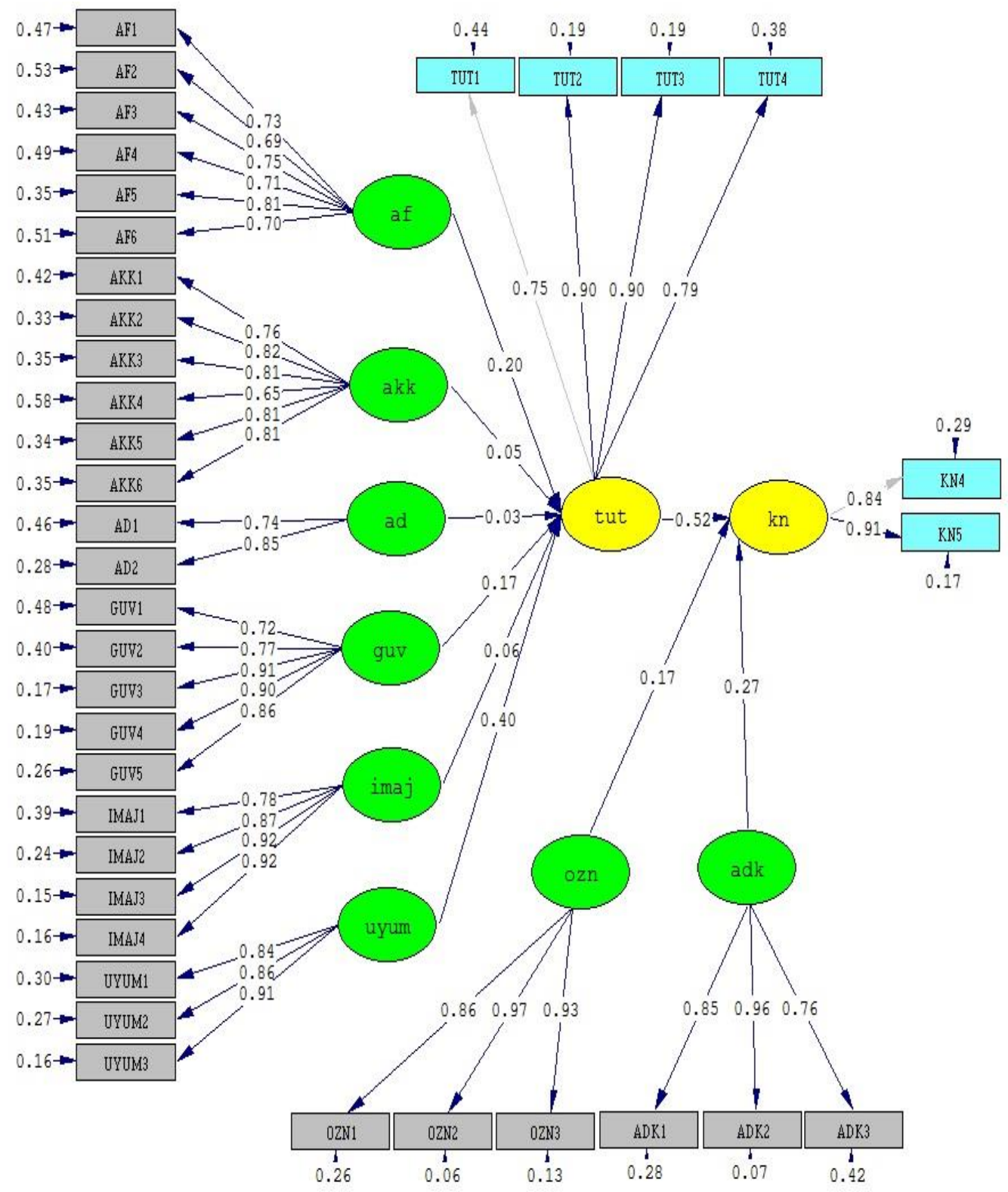

Chi-Square $=1112.86, \mathrm{df}=628, \mathrm{P}-\mathrm{value}=0.00000, \mathrm{RMSEA}=0.055$ 
Ingiltere örneklemi için gerçekleştirilen analiz sonucuna ait yapısal modelin grafiksel gösterimi Şekil 4 'te gösterilmektedir. Ingiltere örneklemine ait yapısal modele ilişkin $\chi^{2}$ değerinin ( $\left.\chi^{2}=1151,07 ; d f=628 ; p=0,00\right)$ anlamlı olduğu görülmektedir. Ayrıca $\chi^{2} / d f=1,83$ olması mükemmel uyuma sahip bir modelin temsil edildiğini göstermektedir. RMSEA değeri $(0,063)^{\prime}$ de kabul edilebilir iyi uyumu ortaya koymaktadır. İngiltere örneklemine ait yapısal modele ilişkin CFI $(0,98)$, NFI $(0,97)$ ve NNFI $(0,98)$ değerleri de modelin mükemmel uyumu sahip olduğunu ortaya koymuştur.

Şekil 4: Ingiltere Örneklemine Ilişskin Yol Diagramı

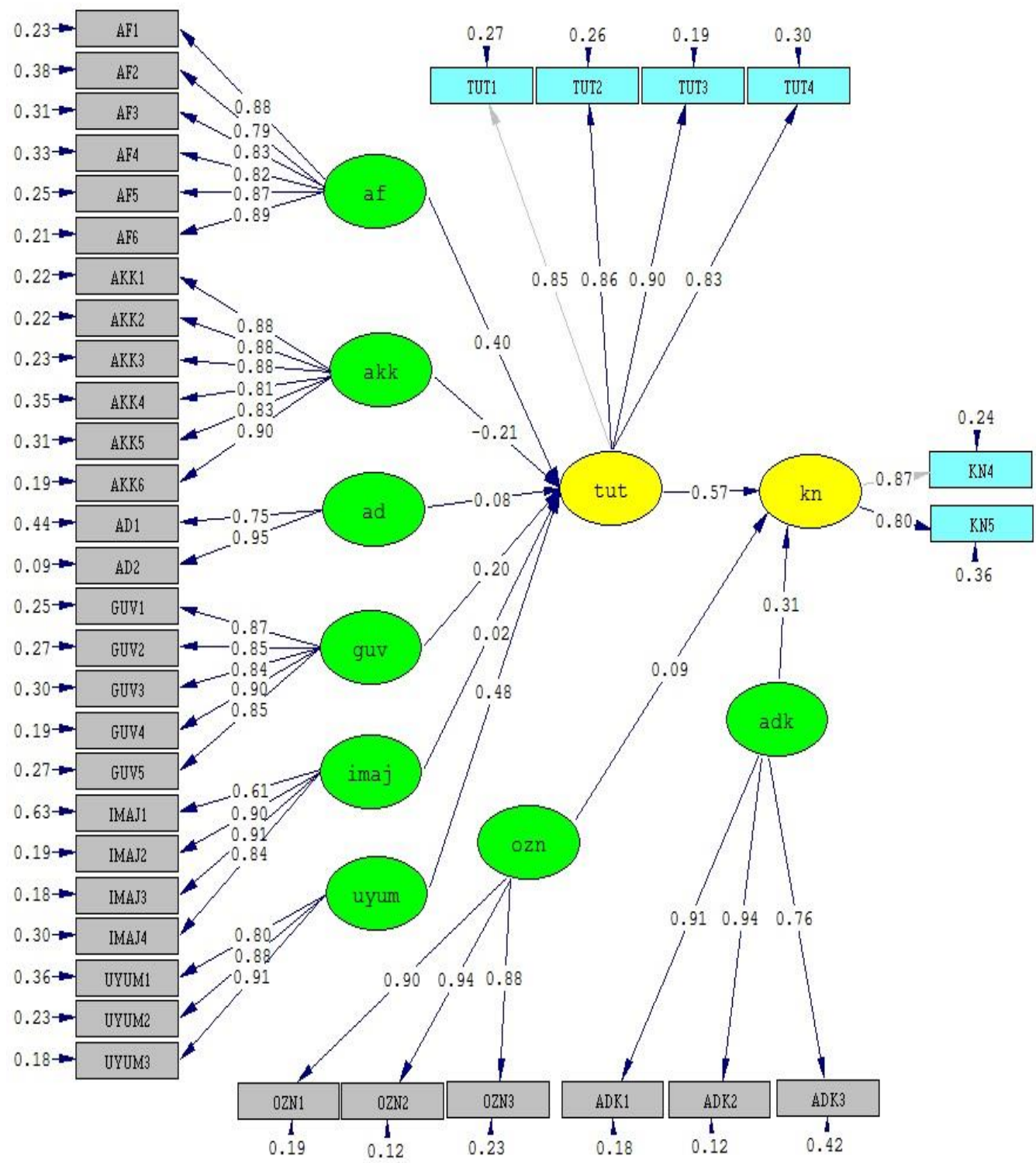

Chi-Square $=1151.07, \mathrm{df}=628, \mathrm{P}-\mathrm{value}=0.00000, \mathrm{RMSEA}=0.063$ 
Örneklem grupları açısından araştırma modeli değerlendirildikten sonra modellerde yer alan gizil değişkenler arasındaki ilişkiyi kontrol etmek ve öne sürülen hipotezleri sınamak için $t$ değerlerinden yararlanılmıştır. Tablo $6^{\prime}$ da araştırma modelinin örneklem grupları için öngörülen ilişkilerine ait standardize edilmiş yol katsayıları ve t değerleri yer almaktadır. Tabloda yer alan değerler incelendiğinde, Türkiye örneklemi için algılanan kullanım kolaylığı ve tutum; algılanan değer ve tutum; algılanan kişisel imaj ve tutum ilişkisinin anlamsız çıktığı $(t<1,96)$ görülmüştür. Bu nedenle Türkiye örneklemi için $\mathrm{H}_{2 a}, \mathrm{H}_{3 a}$ ve $\mathrm{H}_{5 a}$ hipotezleri reddedilmiş ve $\mathrm{H}_{1 a}, \mathrm{H}_{4 a}, \mathrm{H}_{6 a}, \mathrm{H}_{7 a}$, $\mathrm{H}_{8 \mathrm{a}}$ ve $\mathrm{H}_{9 a}$ hipotezleri kabul edilmiştir. İngiltere örneklemi için ise $H_{2 b}, H_{3 b}$ ve $H_{5 b}$ hipotezleri reddedilmiş ve $\mathrm{H}_{1 b}, \mathrm{H}_{4 b}, \mathrm{H}_{6 b}, \mathrm{H}_{7 b}$ ve $\mathrm{H}_{9 b}$ hipotezleri kabul edilmiştir.

Tablo 6: Türkiye ve Ingiltere için Yol Analizi Sonuçları

\begin{tabular}{|c|c|c|c|c|c|c|c|c|c|}
\hline \multicolumn{5}{|c|}{ Türkiye } & \multicolumn{5}{|c|}{ İngiltere } \\
\hline Hipotez & SEYK & t-değeri & $\mathbf{R}^{2}$ & Sonuç & Hipotez & SEYK & t-değeri & $\mathbf{R}^{2}$ & Sonuç \\
\hline $\mathrm{H}_{1 \mathrm{a}}:$ af $\rightarrow$ tut & 0,20 & $2,48 * *$ & & Kabul & $\mathrm{H}_{1 \mathrm{~b}}:$ af $\rightarrow$ tut & 0,40 & $2,81^{*}$ & & Kabul \\
\hline $\mathrm{H}_{2 \mathrm{a}}: \mathrm{akk} \rightarrow$ tut & 0,05 & 0,75 & & Red & $\mathrm{H}_{2 \mathrm{~b}}:$ akk $\rightarrow$ tut & $-0,21$ & $-1,94$ & & Red \\
\hline $\mathrm{H}_{3 \mathrm{a}}:$ ad $\rightarrow$ tut & 0,03 & 0,36 & 0,46 & Red & $\mathrm{H}_{3 \mathrm{~b}}: \mathrm{ad} \rightarrow \mathrm{tut}$ & 0,08 & 1,07 & 0,80 & Red \\
\hline $\mathrm{H}_{4 \mathrm{a}}:$ guv $\rightarrow$ tut & 0,17 & $2,59 *$ & & Kabul & $\mathrm{H}_{4 b}$ : guv $\rightarrow$ tut & 0,20 & $2,47^{* *}$ & & Kabul \\
\hline $\mathrm{H}_{5 \mathrm{a}}$ : imaj $\rightarrow$ tut & 0,06 & 0,94 & & Red & $\mathrm{H}_{5 \mathrm{~b}}$ : imaj $\rightarrow$ tut & 0,02 & 0,47 & & Red \\
\hline $\mathrm{H}_{6 \mathrm{a}}:$ uyum $\rightarrow$ tut & 0,40 & $5,15^{*}$ & & Kabul & $\mathrm{H}_{6 \mathrm{~b}}:$ uyum $\rightarrow$ tut & 0,48 & $4,97^{*}$ & & Kabul \\
\hline $\mathrm{H}_{7 \mathrm{a}}:$ tut $\rightarrow \mathrm{kn}$ & 0,52 & $7,51^{*}$ & & Kabul & $\mathrm{H}_{7 \mathrm{~b}}$ : tut $\rightarrow \mathrm{kn}$ & 0,57 & $6,12^{*}$ & & Kabul \\
\hline $\mathrm{H}_{8 \mathrm{a}}:$ ozn $\rightarrow \mathrm{kn}$ & 0,17 & $3,08^{*}$ & 0,51 & Kabul & $\mathrm{H}_{8 \mathrm{~b}}:$ ozn $\rightarrow \mathrm{kn}$ & 0,09 & 1,74 & 0,74 & Red \\
\hline $\mathrm{H}_{9 \mathrm{a}}: \mathrm{adk} \rightarrow \mathrm{kn}$ & 0,27 & $4,64^{*}$ & & Kabul & $\mathrm{H}_{9 \mathrm{~b}}: \mathrm{adk} \rightarrow \mathrm{kn}$ & 0,31 & $3,56^{*}$ & & Kabul \\
\hline
\end{tabular}

${ }^{*} p<0.01,{ }^{*} p<0.05$, SEYK: Standardize Edilmiş Yol Katsayısı

\section{Sonuç}

Bu araştırma kapsamında elde edilen sonuçlar mobil bankacılığa yönelik algılanan fayda, algılanan güven ve uyumluluğun mobil bankacılığa yönelik tutum üzerinde etkili olduğunu ortaya koymuştur. Elde edilen sonuçlar literatürdeki çalışmalarla (Black vd., 2001; Venkadesh vd., 2003; Wu ve Chen, 2005; Luarn ve Lin, 2005; Aboelmaged ve Gebba, 2013; Wu vd., 2014; Doğan vd., 2015) benzerlik göstermektedir. Mobil bankacılığa yönelik algılanan kullanım kolaylı̆̆ı, algılanan değer ve algılanan kişisel imajın mobil bankacılığa yönelik tutum üzerinde etkisinin olmadığı elde edilen bulgular arasındadır. Bu değişkenlerin tutum üzerindeki etkisini ortaya koyan araştırmalar (Lim vd., 2006; Gefen vd., 2008; Aboelmaged ve Gebba, 2013; Wu vd., 2014; Doğan vd., 2015) olduğu gibi değişkenlerin tutum üzerindeki etkisini anlamsız bulan çalışma (Karahanna vd., 1999; Puschel vd., 2010) örnekleri de vardır. Araştırmada mobil bankacılığa yönelik tutum, öznel norm ve algılanan davranışsal kontrolünde mobil bankacılığı kullanma niyeti üzerinde genel model için etkisinin olduğu görülmüştür. Literatürde bu değişkenlerin niyetin önemli bir belirleyicisi olduğunu ortaya koyan benzer çalışmalar (Taylor ve Todd, 1995a; Shim vd., 2001; Liao vd., 2007; Gu vd., 2009; Puschel vd., 2010; Wu vd., 2014; Doğan vd., 2015) mevcuttur.

Araştırmanın genel modelinde mobil bankacılığa yönelik tutumun algılanan kullanım kolaylığı, algılanan fayda, algılanan güven, algılanan kişisel imaj, algılanan değer ve uyumluluk değişkenleri tarafından açıklanma oranı Türkiye örneklemine göre biraz daha fazla iken, 
Ingiltere örneklemine göre daha azdır. Benzer şekilde genel modelde yer alan mobil bankacılığı kullanma niyetinin de mobil bankacılığı kullanmaya yönelik tutum, öznel norm ve algılanan davranışsal kontrol değişkenleri tarafından açıklanma oranı İngiltere'ye göre daha az iken, Türkiye'ye göre daha yüksektir. Çok gruplu yol analizi sonucu elde edilen sonuçlar öne sürülen araştırma modelinin ülke grupları açısından farklılaştığını göstermektedir. Diğer bir ifadeyle, Ingiltere örneklem grubunda öznel normun mobil bankacılığı kullanma niyeti üzerindeki anlamsız etkisi, Türkiye için anlamlı bulunmuştur. Her iki ülke grubu için algılanan kullanım kolaylı̆̆ı, algılanan değer ve algılanan kişisel imajın mobil bankacılığa yönelik tutum üzerindeki etkisi anlamsızdır. Çünkü kollektivist toplumlarda bireyler içinde bulundukları gruplardan ayrılamazlar (Öncül vd., 2016). Bu çerçevede Tükiye örneklemi için davranışsal niyet üzerinde öznel normun etkili olması manidardır.

Araştırmanın Teknoloji Kabul Modeli ve Planlı Davranış Teorisi literatürü açısından önemli katkılar sağladığını ifade etmek mümkündür. Araştırmanın modeli bireylerin mobil bankacılık uygulamalarını kullanmaya yönelik tutumları ve kullanma niyetleri üzerinde etkisi olduğu düşünülen bir takım değişkenleri (algılanan fayda, algılanan kullanım kolaylı̆̆ı, öznel norm, algılanan davranışsal kontrol) ortaya çıkarmaktadır. Ayrıca mevcut teorilere yeni değişkenlerin (algılanan güven, algılanan değer, uyumluluk, algılanan kişisel imaj) eklenmesiyle bütünleşik bir model oluşturulmuş ve mobil bankacılığa yönelik tutum üzerindeki etkenlerin daha geniş bir perspektiften sunulması sağlanmıştır. Literatürde bütünleşik modeller kullanılarak yapılmış çalışmalar (Brown vd., 2002; Venkatesh, 2003; Wu ve Chen, 2005; Wu ve Wang, 2005; Pedersen, 2005; Fu vd., 2006; Chen vd., 2007; Khalifa ve Shen, 2008; Tung vd., 2008; Zhou vd., 2010; Aboelmaged ve Gebba, 2013, Wu vd., 2014; Doğan vd., 2015) niyetin açıklayıcılı̆̆ını artırdığını göstermektedir. Bu kapsamda öne sürülen modellerin uyum değerleri elde edilen verinin teorik model ile uyumlu olduğunu göstermiştir.

Bankacılık sektörü ve pazarlama uygulayıcıları açısından şüphesiz en önemli unsur müşterilerdir. Bu nedenle ele alınan bu araştırma, teknolojik gelişmeye bağlı olarak kendini sürekli yenilemek zorunda olan bankacılık sektörünün müşterilerine sundukları ürünler hakkında sahip olunan tutumların ve kullanma davranışlarının oluşmasında etkili olabilecek öğelerin ortaya çıkarılması açısından faydalı olacaktır.

Bankalar, rekabette başarılı olabilmek için müşterilerine sağladıkları hizmetlerin sunumunda fark yaratmaya çalışarak pazarlama stratejilerini uygulamaya çalışmaktadırlar. Bu amaçla mevcut müşterilerini elde tutmak, onlardan daha fazla verim almak ve potansiyel müşterilere ulaşmak için mobile daha fazla yönelerek onların istek ve ihtiyaçlarını karşılama çabası içine girmelidirler. Çünkü dijitalleşmenin getirmiş olduğu yenilikler, tüketici satın alma davranışının da mobille kontrol edilebilmesine olanak tanımaya başlamıştır. Mobilite unsurunun önümüzdeki süreçte daha çok ön plana çıkacağı düşünüldüğünde, bankaların mevcut şube stratejileri değiş̧ecektir. Mobil bankacılığın giderek daha çok tercih edilmesiyle beraber bankacılık sektörünün rekabette öne geçebilmesi, müşterilerin istek ve ihtiyaçlarının karşılanabilmesi için bu alana yatırımlarını artırması ve hızlandırması gerekmektedir.

Bu araştırmanın ilk kısıtı niyet değişkeni ile ilgilidir. PDT'ye göre niyetin belirli şartlar altında davranışa dönüşmesi gerekmektedir (Ajzen, 1991). Ancak davranışın ölçümü mevcut koşullar altında zaman ve imkan bakımından zor görünmektedir. Bu nedenle bağımlı değişken olarak sadece niyet ölçülmüştür. Araştırmanın ikinci kısıtını ise kullanılan örnekleme yöntemi oluşturmaktadır. Olasılıklı örnekleme yöntemlerinin maliyet ve zaman açısından fazla olması nedeniyle kolayda örnekleme yöntemi kullanılmıştır. Ayrıca araştırmanın anakütle kısıtını 
Türkiye ve Ingiltere'de yaşayan ve mobil bankacılık uygulamalarını kullanan bireyler oluşturmaktadır.

Mobil pazarlama uygulamaları anlamında sunulan hizmetlerin kullanımına yönelik ülkeler bakımdan karşılaştırmaların yapıldığı araştırma sayısının az olması (Varnalı ve Toker, 2010; Shaikh ve Karjaluoto, 2015) dikkate alınarak gerçekleştirilen bu çalışmada Türkiye ve İngiltere seçilmiş, bu ülkelerde yaşayan bireylerin mobil bankacılık uygulamalarını kullanma niyeti karşılaştırmalı olarak incelenmiş̧ir. Bu kapsamda farklı ülkelerde araştırmanın hipotezleri test edilerek ülkelerarası karşılaştırma yapılmıştır. Benzer şekilde, bundan sonra gerçekleştirilecek araştırmalarda farklı ülke karşılaştırmaları yapılması önerilmektedir. Ülkeler arasında karşılaştırma yapılması tüketicilerin davranışlarının ve uygulanacak olan pazarlama stratejilerinin tespitinde önemli bilgiler sunacaktır.

Gelecekte yapılması planlanan çalışmalarda bu araştırma kapsamında öne sürülen genel model ve ülke grubuna göre ortaya çıkan modellere ait hipotezlerin farklı örneklem, farklı ürün grupları üzerinde tekrar sınanması önerilebileceği gibi, bu araştırma kapsamında elde edilen modeller de kullanılabilir. Ayrıca çalışmada elde edilen modelin farklıııklarını ortaya çıkaracak veya önemli etkileri olabileceği düşünülen farklı değişkenlerinde diğer araştırmalarda dikkate alınması mümkündür. 


\section{Kaynakça}

Aboelmaged, Mohamed Gamal; Gebba, Tarek R. (2013), "Mobile Banking Adoption: An Examination of Technology Acceptance Model and Theory of Planned Behavior", International Journal of Business Research and Development, Vol:2, No:1, pp.35-50.

Ajzen, Icek, (1985), "From Intentions to Actions: A Theory of Planned Behavior", Action Control, From Cognition to Behaviour, Julius, KUHL ve Jürgen, BECKMAN, (Ed.), Springer Verlag Berlin Heidelberg, pp. 11-39.

Ajzen, Icek, (1991), "The Theory of Planned Behavior", Organizational Behavior and Human Decision Processes, Vol:50, pp.179-211.

Ajzen, Icek, (2005), Attitudes, Personality and Behavior, Open University Press, Second Edition, England.

Barnes, Stuart J.; Corbitt, Brian, (2003), "Mobile Banking: Concept and Potential", International Journal of Mobile Communications, Vol:1, No:3, pp.273-288.

Barutçu, Süleyman, (2008), "Mobil Pazarlama", Güncel Pazarlama Yaklaşımlarından Seçmeler, İnci, VARiNLi ve Kahraman, ÇATI, (Ed.), Detay Yayıncılık, Ankara, ss.259-285.

Black, Nancy Jo; Lockett, Andy; Ennew, Christine; Winklhofer, Heidi; Mckechnie, Sally, (2001), "Modelling Consumer Choice of Distribution Channels: An Illustration from Financial Services", International Journal of Bank Marketing, Vol:20, No:4, pp.161-173.

Brown, S.A.; Massey, A.P.; Montoya-Weiss, M.M.; Burkman, J. R. (2002), "Do I Really Have to? User Acceptance of Mandated Technology", European Journal of Information Systems, Vol:11, No:4, pp.283-295.

Chen, Chun-Der; Fan, Yi-Wen; Farn, Cheng-Kiang, (2007), "Predicting Electronic Toll Collection Service Adoption: An Integration of the Technology Acceptance Model and the Theory of Planned Behavior", Transportation Research, Vol:15, No:5, pp.300-311.

Cheng, T.C. Edwin; Lam David Y.C.; Yeung, Andy C.L. (2006), "Adoption of Internet Banking: An Empirical Study in Hong Kong", Decision Support Systems, Vol:42, pp. 1558-1572.

Cheung, Gordon W.; Rensvold, Roger B. (2002), "Evaluating Goodness of Fit Indexes for Testing Measurement Invariance", Structurel Equation Modeling, Vol:9, No:2, pp.233-255.

Chiu, Yu-Bin; Lin, Chieh-Peng; Tang, Ling-Lang, (2005), "Gender Differs: Assessing a Model of Online Purchase Intentions in E-tail Service", International Journal of Service Industry Management, Vol:16, No:5, pp.416-435.

Davis, Fred D., Bagozzi, Richard P.; Warshaw, Paul R. (1989), "User Acceptance of Computer Technology: A Comparison of Two Theoretical Models", Management Science, Vol:35, No:8, pp.982-1003.

Doğan, Murat; Şen, Rana; Yılmaz, Veysel, (2015), "İnternet Bankacılığına İlişkin Davranışların Planlanmış Davranış Teorisi ve Teknoloji Kabul Modeli Kullanılarak Önerilen Bir Yapısal Eşitlik Modeliyle İncelenmesi", Uşak Üniversitesi Sosyal Bilimler Dergisi, Sayı:22, ss.1-22.

Fishbein, Martin; Ajzen, Icek, (1975), Belief, Attitude, Intention and Behavior: An Introduction to Theory and Research, Addison-Wesley Publishing, Canada.

Fu, Jen-Ruei; Farn, Cheng-Kiang; Chao, Wen-Pin, (2006), "Acceptance of Electronic Tax Filing: A Study of Taxpayer Intentions", Information \& Management, Vol:43, No:1, pp.109-126.

Gallarza, Martina G.; Saura, Irene Gil, (2006), "Value Dimensions, Perceived Value, Satisfaction and Loyalty: An Investigation of University Students' Travel Behaviour", Tourism Management, Vol:27, pp.437-452.

Gefen, David; Karahanna, Elena; Straub, Detmar W. (2003), "Trust and TAM in Online Shopping: An Integrated Model", MIS Quarterly, Vol:27, No:1, pp.51-90.

Gefen, David; Benbasat, Izak; Pavlou, Paul A. (2008), "A Research Agenda for Trust in Online Environment", Journal of Management Information Systems, Vol:24, No:4, pp.275-286.

Gu, Ja-Chul; Lee, Sang-Chul; Suh, Yung-Ho, (2009), "Determinants of Behavioral Intention to Mobile Banking", Expert Systems with Applications, Vol:36, pp. 11605-11616.

Guriting, Petrus; and Ndubisi; Nelson Oly, (2006), "Borneo Online Banking: Evaluating Customer Perceptions and Behavioral Intention", Management Research News, Vol:29, No:1/2, pp.6-15.

Hair, Joseph F.; BLACK, William C.; Babin, Baryy J.; Anderson, Rolph E. (2010), Multivariate Data Analysis, Seventh Edition, Prentice Hall, NewYork.

Hanafizadeh, Payam; Behboudi, Mehdi; Koshksaray, Amir Abedini; Tabar, Marziyeh Jalilvand Shirkhani, (2014), "Mobile-Banking Adoption by Iranian Bank Clients", Telematics and Informatics, Vol:31, No:1, pp.62-78. 


\section{Eskişehir Osmangazi Üniversitesi IïB Dergisi}

https://www.bba.org.uk/news/reports/an-app-etite-for-banking/\#.WiqJq1VI-po (Erişim: 12.11.2017)

https://www.ingbank.com.tr/F/Documents/pdf/Basin_Odasi/2014/INGBank_DijitalCagArastirmasi_26092014.docx.p df (Erişim: 11.11.2017)

https://www.tbb.org.tr/tr/banka-ve-sektor-bilgileri/istatistiki-raporlar/Dijital,_ ve_Mobil_Bankacilik_Istatistikleri/3671 (Erişim: 03.02.2018)

Internet_

Ilie, Virginia; Slyke, Craig Van; Green, Gina; Lou, Hao, (2005), "Gender Differences in Perceptions and Use Communication Technologies: A Diffusion of Innovation Approach", Information Resources Management Journal, Vol:18, No:3, pp.13-31.

Jarvenpaa, Sirkka L.; Tractinsky, Noam; Vitale, Michael, (2000), "Costumer Trust in An Internet Store", Information Technology and Management, Vol:1, pp.45-71.

Karahanna, Elena; Straub, Detmar W.; Chervany, Norman L. (1999), "Information Technology Adoption Across Time: A Cross-Sectional Comparison of Pre-Adoption and Post-Adoption Beliefs", MIS Quarterly, Vol:23, No:2, pp.183-213.

Khalifa, Mohamed; Shen, Kathy Ning, (2008), "Explaining the Adoption of Transactional B2C Mobile Commerce", Journal of Enterprise Information Management, Vol:21, No:2, pp.110-124.

Khraim, Hamza Salim; Al Shoubaki, Younes Ellyan; Khraim, Aymen Salim, (2011), "Factors Affecting Jordanian Consumers' Adoption of Mobile Banking Services", International Journal of Business and Social Science, Vol:2, No:20, pp.96-105.

Kim, Gimun; Shin, BongSik; Lee, Ho Geun, (2009), "Understanding Dynamics Between Initial Trust and Usage Intentions of Mobile Banking", Information Systems Journal, Vol:19, No:3, pp.283-311.

Kim, Hee-Woong; Chan, Hock Chuan; Gupta, Sumeet, (2007), "Value-Based Adoption of Mobile Internet: An Empirical Inverstigation", Decision Support Systems, Vol:43, pp.111-126.

Kline, Rex B., (2011), Principles and Practice of Structural Equation Modeling, Third Edition, The Guilford Press, London.

Koenig-Lewis, Nicole; Palmer, Adrian; Moll, Alexander, (2010), "Predicting Young Consemers' Take Up of Mobile Banking Services", International Journal of Bank Marketing, Vol:28, No:5, pp.410-432.

Lai, Jung-Yu; Yang, Chun-Chieh, (2009), "Effects of Employees' Perceived Dependability on Success of Enterprise Applications in E-business", Industrial Marketing Management, Vol:38, pp.263-274.

Li, Dahui; Browne, Glenn J.; Chau, Patrick Y. K. (2006), "An Empirical Investigation of Web Site Use Using a CommitmentBased Model", Decision Sciences, Vol:37, No:3, pp.427-444.

Liao, Checken; Chen, Jain-Liang; Yen, David C. (2007), "Theory of Planning Behavior (TPB) and Customer Satisfaction in the Continued Use of E-service: An Integrated Model", Computers in Human Behavior, Vol:23 No:6, pp. 2804-2822.

Lim, Kai H.; Sia, Choon Ling; Lee, Matthew K. O.; Benbasat, Izak, (2006), "Do I Trust You Online, and If So, Will I Buy? An Empirical Study of Two Trust-Building Strategies", Journal of Management Information Systems, Vol:23, No:2, pp.233-266.

Lin, Hsiu-Fen, (2011), "An Empirical Investigation of Mobile Banking Adoption: The Effect of Innovation Attributes and Knowledge-Based Trust", International Journal of Information Management, Vol:31, pp.252-260.

Luarn, Pin; Lin, Hsin-Hui, (2005), "Toward an Understanding of The Behavioral Intention to Use Mobile Banking", Computers in Human Behavior, Vol:21, pp.873-891.

Mcknight, D. Harrison; Choudhury, Vivek; Kacmar, Charles, (2002), "Developing and Validating Trust Measures for ECommerce: An Integrative Typology", Information Systems Research, Vol:13, No:3, pp.334-359.

Moore, Gary C.; Benhasat, Izak, (1991), "Development of An Instrument to Measure the Perceptions of Adopting An Information Technology Innovation", Information System Research, Vol:2, No:3, pp.192-222.

Öncül, Mehmet Sadık; Deniz, Mehmet; İnce, Ali Rıza, (2016), "Hofstede'nin Örgüt Kültürü Modelinin Potansiyel Girişimcilerin Yetiştiği Çevresel Özellikler Kapsamında Değerlendirilmesi", Akademik Yaklaşımlar Dergisi, Cilt: 7, Sayı: 1, ss. 255-269.

Pavlou, Paul A.; Fygenson, Mendel, (2006), "Understanding and Predicting Electronic Commerce Adoption: An Extension of the Theory of Planned Behavior", MIS Quarterly, Vol:30, No:1, pp.115-143.

Pedersen, Per E., (2005), "Adoption of Mobile Internet Services: An Exploratory Study of Mobile Commerce Early Adopters", Journal of Organizational Computing, Vol:15, No:3, pp.203-222.

Puschel, Julio; Mazzon, Jose Afonso; Hernandez, Jose Mauro, C. (2010), "Mobile Banking: Proposition of An Integrated Adoption Intention Framework", International Journal of Bank Marketing, Vol:28, No:5, pp.389-409. 
Ramayah, Thurasamy; Ignatius, Joshua; Aafaqi, Bushra, (2005), "PC Usage Among Students in a Private Institution of Higher Learning: The Moderating Role of Prior Experience", Jurnal Pendidik dan Pendidikan, Vol:20, pp.131-152.

Riquelme, Hernan E.; Rios, Rosa E. (2010), "The Moderating Effect of Gender in the Adoption of Mobile Banking", International Journal of Bank Marketing, Vol:28, Iss:5, pp.328-341.

Rogers, Everett M., (1983), Diffusion of Innovation, Third Edition, Macmillan Publishing Co., New York.

Shaikh, Aijaz A.; Karjaluoto, Heikki, (2015), "Mobile Banking Adoption: A Literature Review", Telematics and Informatics, Vol:32, pp.129-142.

Shim, Soyeon; Eastlick, Mary Ann; Lotz, Sherry L.; Warrington, Patricia, (2001), "An Online Prepurchase Intentions Model: The Role of Intention to Search", Journal of Retailing, Vol:77, pp.397-416.

Sirdeshmukh, Deepak; Singh, Jagdip; Sabol, Barry, (2002), "Consumer Trust, Value, and Loyalty in Relational Exchanges", Journal of Marketing, Vol:66, pp.15-37.

Şıker, Perihan, (2011), "Müşterilerin İnternet Bankacılığını Benimsemelerine Yönelik Keşifsel Bir Araştırma", Internet Uygulamaları ve Yönetimi Dergisi, Sayı:2, ss.35-50.

Şimşek, Ömer Faruk, (2007), Yapısal Eşitlik Modellemesine Giriş: Temel IIlkeler ve LISREL Uygulamaları, Ekinoks Yayınları, Ankara.

Taylor, Shirley; Todd, Peter A. (1995a), "Understanding Information Technology Usage: A Test of Competing Models", Information Systems Research, Vol:6, No:2, pp.144-176.

Tiwari, Rajnish; Buse, Stephan; Herstatt, Cornelius, (2007), "Mobile Services in Banking Sector: The Role of Innovative Business Solutions in Generating Competitive Advantage", Proceeding of the International Research Conference on Quality, Innovation and Knowledge Management, New Delhi, pp.886-894.

Tung, Feng-Cheng; Chang, Su-Chao; Chou, Chi-Min, (2008), "An Extension of Trust and TAM Model with IDT in the Adoption of the Electronic Logistics Information System in HIS in the Medical Industry", International Journal of Medical Informatics, Vol:77, No:5, pp.324-335.

Varnalı, Kaan; Toker, Ayşegül, (2010), "Mobile Marketing Research: The-state-of-the-art", International Journal of Information Management, Vol: 30, pp.144-151.

Venkatesh, Viswanath; Davis, Fred D. (2000), "A Theoretical Extension of the Technology Acceptance Model: Four Longitudinal Field Studies", Management Science, Vol:46, No:2, pp.186-204.

Venkatesh, Viswanath; Morris, Michael G.; Davis, Gordon B.; Davis, Fred D. (2003), "User Acceptance of Information Technology: Toward a Unified View", MIS Quarterly, Vol:23, No:3, pp.425-478.

Vijayasarathy, Leo R., (2004), "Predicting Consumer Intentions to Use On-line Shopping: The Case for an Augmented Technology Acceptance Model", Information and Management, Vol:41, pp.747-762.

Vurucu, Mehmet; Arı, Ufuk, (2015), Güncel Gelişmeler Işığında Bankacılık Ürün ve Hizmetleri: Bireysel - Özel - Yatırım - KOBI - Ticari - Kurumsal Bankacılık, Seçkin Yayıncılık, Ankara.

Wang, Yi-Shun; Lin, Hsin-Hui; Luarn, Pin, (2006), "Predicting Consumer Intention to Use Mobile Service", Information Systems Journal, Vol:16, pp. 157-179.

Wu, Amery D., Li, Zhen; Zumbo, Bruno D. (2007), "Decoding the Meaning of Factorial Invariance and Updating the Practice of Multi-group Analysis: A Demonstration With TIMSS Data", Practical Assessment, Research \& Evaluation, Vol:12, No:3, pp.1-26.

Wu, Ing-Long; Chen, Jian-Liang, (2005), "An Extension of Trust and TAM Model with TPB in the Initial Adoption of online Tax: An Empirical Study", International Journal of Human-Computer Studies, Vol:62, No:6, No:784-808.

Wu, Jen-Her; Wang, Shu-Ching, (2005), "What Drives Mobile Commerce? An Empirical Evaluation of The Revised Technology Acceptance Model", Information and Management, Vol:42, pp.719-729.

Wu, Meimei; Jayawardhena, Chanaka; Hamilton, Robert, (2014), "A Comprehensive Examination of Internet Banking User Behaviour: Evidence From Customers yet to Adopt, Currently Using and Stopped Using", Journal of Marketing Management, Vol:30, Iss:9-10, pp.1006-1038.

Yoon, H. S.; Steege, L. M. B. (2013), "Development of a quantitative model of the impact of customers' personality and perceptions on internet banking use", Computer in Human Behavior, 29, 1133-1141. doi:10.1016/j.chb.2012.10.005

Zandhessami, Hessam; Geranmayeh, Parisa, (2014), "Determinants of User Acceptance of Internet Banking: An Empirical Study", Management Science Letters, Vol:4, pp.1369-1374. 


\section{Eskişehir Osmangazi Üniversitesi iiBF Dergisi}

Zeithaml, Valarie A., (1988), "Consumer Perceptions of Price, Quality and Value: A Means-End Model and Synthesis of Evidence", Journal of Marketing, Vol:52, No:3, pp.2-22.

Zhou, Tao; Lu, Yaobin; Wang, Bin, (2010), "Integrating TTF and UTAUT to Explain Mobile Banking User Adoption", Computers in Human Behavior, Vol:26, pp.760-767. 


\title{
Extended Summary
}

\author{
Determinants of Customer' Intention to Use M-Banking Apps: A Cross-Nation Study
}

\begin{abstract}
Consumers are undoubtedly the most important factor for the banking sector and marketing practitioners. Banks are trying to make a difference in the provision of services they provide to their customers in order to be successful in the competition. To this end, they want to retain their existing customers. Again, in order to reach potential customers, they turn to mobile and try to meet their needs and needs. Because the innovations brought by digitalization have started to allow the control of consumer purchasing behavior with mobile. Given the fact that the mobility element will become more prominent in the coming period, the existing branch strategies of the banks will change. As mobile banking is increasingly preferred by consumers, the banking sector needs to increase and accelerate its investments in this field in order to take the lead in competition and meet the needs and needs of customers. Therefore, it becomes an important issue to investigate which factors affect the attitudes of customers towards mobile banking applications.
\end{abstract}

The purpose of this paper is to investigate the factors affecting on customers' attitude and intention to continually use $\mathrm{m}$-banking application(s). All constructs of the technology acceptance model and theory of planned behaviour are studied. Further, perceived value, trust, image and compatibility are also included to predict attitude. The intention to continuosly use m-banking apps is influenced by variables of attitudes, subjective norms and perceived behavioral control. Furthermore, variables are that perceived usefulness, perceived ease of use, perceived value, trust, image and compatibility affect attitudes towards m-banking apps.

Measuring scales were adopted from the literature and all items were measured on a five-point Likert scale. A pilot test of constructs was conducted on a reprentative sample of 13 people from England and 19 people from Turkey, and questionnaire statements were modified based on the results of the pilot test. Measures of demographic factors include gender, age, education, the frequency of using mobile banking applications and the most used service. A conceptual model is presented, which is empirically tested with 466 respondents from 256 participants in Turkey and 208 participants in England. The survey method was used for collecting data to test the hypotheses. The data were analyzed using structural equation modelling (LISREL) and multi-group analysis. The main hypothesis of this study is that the research model differs according to country group. The other hypotheses of our study are:

The level of perceived usefulness by consumers using mobile banking applications affects the attitude towards mobile banking.

The level of perceived ease of use by consumers using mobile banking applications affects the attitude towards mobile banking.

The level of perceived value of consumers using mobile banking applications affects the attitude towards mobile banking.

The level of perceived trust by the consumers using mobile banking applications affects the attitude towards mobile banking.

The level of perceived personal image by consumers using mobile banking applications affects the attitude towards mobile banking.

The level of perceived compatibility by the consumers using mobile banking applications affects the attitude towards mobile banking.

The attitude level of consumers using mobile banking applications towards mobile banking affects their intention to use.

The subjective norm level of the consumers using mobile banking applications affects their intention to use.

The level of perceived behavioral control by consumers using mobile banking applications affects their intention to use them.

After the measuring model was accepted and to show invariance across Turkey and England, we proceeded to test the main hypotheses. The structural model was analysed by testing the direct effects by estimating the relations and the testing the effects by using a multi-group path analysis.

The hypotheses testing results of the direct relationships contained in two groups. We find that attitude to $\mathrm{m}$ banking apps is the most important construct that is positively and directly related to using intention. Also, subjetive norms and perceived behavioral control were found directly influence using intention. Perceived usefulness, trust ve compatibility were found in this study to directly influence attitude to $m$-banking apps. Additionally, the direct effects of perceived ease of use, value and image were not found to be significant influence on attitude. 


\section{Eskişehir Osmangazi Üniversitesi IïBF Dergisi}

Structural equation model analysis results of multi-group path analysis (Turkey and England) is that attitude to $\mathrm{m}$ banking apps and perceived behavioral control are positively related to using intention both Turkey and England. While perceived value, trust and compatibility were found directly influence attitude to $\mathrm{m}$-banking apps; perceived ease of use, perceived value and image were not found to be significant influence both Turkey and England. Finally, subjective norm was found influence on using intention at Turkey sample but not having effect at England sample.

The practical implications of the study is that data were collected from customers of using $m$-banking apps in Turkey and England. Future research should be expanded to include other countries and conductes to test the factors identified in literature on other innovations. The practical implications of the research will help to banks for $\mathrm{m}$-banking applications and understanding customer' needs. So, customers will have continuous intends to use the mobile banking apps. The originality/value of this study enhances understanding of customer attitude and continuous use intention toward m-banking apps. The research model is tested in two countries (Turkey and England) and offers a comparison on the basis of developed and developing countries. 